\title{
THE EQUITY FOR VISUAL ARTISTS ACT OF 2011 (EVAA): CRAFTING AN EFFECTIVE RESALE ROYALTY SCHEME FOR THE UNITED STATES THROUGH COMPARATIVE MEDITATION
}

\author{
Elisa D. Doll ${ }^{*}$
}

"A visible and tangible artwork is a kind of persisting event. One or more artists made it at a certain time and in a specific place, even if no one knows just who, when, where, or why. Although created in the past, an artwork continues to exist in the present, long surviving its times. The first painters and sculptors died thirty thousand years ago, but their works remain ...." - Gardner's Art Through the Ages ${ }^{1}$

"Recognition of the role of copyright and related rights leads us to see that artists face a problem of optimizing their earnings over time. ... Why artists should have to suffer for their art is an equity question that economists cannot easily discuss."

- Ruth Towse ${ }^{2}$

\section{INTRODUCTION}

In recognition of the special relationship that exists between authors and their work, international copyright laws sometimes provide resale royalties for visual artists - a legal right otherwise known as the droit de suite (French for "right to follow"). ${ }^{3}$ Resale royalty legislation is

* J.D., 2013, Indiana University Robert H. McKinney School of Law; B.S., 2010, Kelley School of Business, Indiana University, Indianapolis, Indiana. I would like to thank Professor Lea Shaver, Associate Professor of Law, who contributed her considerable expertise in writing and was endlessly supportive. I am especially thankful for the day that Prof. Shaver placed a copy of Madhavi Sunder's book, From GoOdS TO A GoOd LifE: Intellectual Property and Global Justice, in my hands. See infra note 6. Prior to reading this book, I never had occasion to question the United States' almost singular focus on the trade-off between incentivizing the creation of works and public access to those works. I also wish to give thanks to the reference staff of the Ruth Lilly Law Library, Indiana University Robert H. McKinney School of Law - particularly, Constance Matts and Richard Humphrey who are adept at finding the un-findable. Finally, I would like to thank my family for all of their love and support throughout the writing process. As indicated in Appendix B, additional research is available on a companion WordPress website at http://elisadoll.wordpress.com/.

1. Gardner's Art Through the Ages xxxiii (David Tatom ed., 11th ed. 2001).

2. Ruth Towse, Market Value \& Artists' Earnings, the Value of Culture: On the Relationship Between Economics AND ARts 97-99 (Arjo Klamer ed., Amsterdam University Press 1996).

3. Christina Saunders, The Resale Right: American Copyright Law and the Moral Right, Nouveau LAw, LLC (May 15, 2012), http:/www.nouveaulaw.com/art-news/theresale-right-american-copyright-law-and-the-moral-right/, archived at http://perma.cc/5B2G- 
occasionally described academically as another stick in the bundle of intellectual property rights commonly referred to as "le droit moral" or "moral rights," especially when discussing its remedial purpose. ${ }^{4}$ But in practice, it is often described as an "economic right" because of an inherently fiscal aspect that causes it to differ from other more vague or elusive moral rights. ${ }^{5}$ The apparent classification conflict between the economic and equitable aspects of resale royalty rights can create several hurdles to designing and implementing effective legislation from inception.

Despite such difficulties, more than fifty countries have adopted some type of resale royalty legislation. ${ }^{6}$ The federal United States has historically been reluctant to do so. ${ }^{7}$ The United States likely abstained initially from adopting some form of this right because of the sweeping changes ratification would require to an arguably increasingly mercantilist Copyright system $^{8}$ that relied heavily on formalities in copyright

GGA6.

4. See generally Simon Stokes, ARt And Copyright 83-109 (Hart Publ'g 2d ed. 2012) (discussing the resale right in the context of moral rights).

5. Id. at 97 (discussing how to classify the right is debatable); $c f$. Marina Santillini, United States' Moral Rights Developments in European Perspective, 1 MarQ. InTEll. PROP. L. REV. 89, 106-07 (1997) (discussing the strong academic distinction between the resale right and moral rights but suggesting that resale royalties complement or supplement moral rights). The difficulty in classification likely arises from inalienability. Without this element, it is easier to say the right is not tied to the author and is, therefore, economic.

6. Contemporary Art Galleries Association, Establishing the Artists' Resale Right in CANAda: Bill C-11-Copyright 3 (2011), archived at http://perma.cc/PU2K-35WE.

7. See Katreina Eden, Fine Artists' Resale Royalty Right Should Be Enacted in the United States, 18 N.Y. InT'L L. REV. 121, 127-36 (2005); see also LiLIANE DE PiERrEdonFawcett, The Droit de Suite in Literary and Artistic Property: A Comparative LAW Study 99 (John M. Kernochan ed., Louise-Martin-Valiquette trans., Columbia Univ. School of Law 1991). Resale royalty legislation was incorporated into the Berne Convention for the Protection of Literary and Artist Works of 1886 (the Berne Convention) in 1948 at Brussels and adopted by several other countries but was not embraced by the United States in any major way, until it adopted the Visual Artists' Rights Act of 1990 (VARA). Stephanie B. Turner, The Artist's Resale Royalty Right: Overcoming the Information Problem, 19 UCLA ENT. L. REV. 329, 340 (2012) (discussing how VARA as enacted did not contain a resale royalty provision but directed the Copyright Register to perform a feasibility study for implementation in the United States).

8. Madhavi Sunder, From Goods to a Good Life: Intellectual Property and Global Justice 23-32 (Yale Univ. Press 2012) ("mercantilist" is describing Sunder's view that constitutionally mandated "progress" is equivalent to maximum creative output). Under this view, legislation is perpetuated based upon an economic rationale comporting with utilitarian business economics that is overly narrow-balancing incentives versus access - because it fails to address the practical import of the legislation. Sunder suggests this view is problematic because it necessarily "reduces to the claim that the ability to pay [to exchange money for goods, in other words, commercial activity], as evidenced by the marketplace, should determine the production and distribution of knowledge and culture [for society as a whole]." Id. at 29 (alterations added); see also Saunders, supra note 3 (discussing how the United States emphasizes profits over personalty). 
application. $^{9}$

Despite federal reluctance, at least twelve states had individually adopted some type of moral rights legislation by $1990 .{ }^{10}$ Resale royalties, however, remained unpopular. To date, California is the only state to move such a law, as it is traditionally conceived, beyond the proposal stage - the California Resale Royalty Act of 1977 (CRRA). ${ }^{11}$ However, two other states, Georgia and South Dakota, each have adopted extremely narrow renditions that are applicable only to state-owned works of visual art. ${ }^{12}$ Further, the US territory of Puerto Rico has adopted a resale royalty right. ${ }^{13}$

Discussions of federal resale royalty legislation for the United States have been largely theoretical, but in late 2011 the talk turned into action for several reasons. First, in late 2011, a combined class-action suit was filed against auction power-houses Sotheby's, Christie's, and eBay under the CRRA. ${ }^{14}$ The suit was later dismissed by the District Court for the Central

9. Jimmy A. Frazier, On Moral Rights, Artist-Centered Legislation, and the Role of the State in Art Worlds: Notes on Building a Sociology of Copyright Law, 70 TUL. L. Rev. 313, 342 (1995); see also Robert C. Bird, Moral Rights: Diagnosis and Rehabilitation, 46 Ам. Bus. L.J. 407, 414-26 (2009); see generally Copyright Act of 1909, 17 U.S.C.A. § 101, repealed by 90 Stat. 2541 (West 2012) (discussing in more detail information about the four requirements of notice, publication, registration and deposit).

10. Channah Farber, Comment, Advancing the Arts Community in New Mexico through Moral Rights and Droit de Suite: The International Impetus and Implications of Preemption Analysis, 36 N.M. L. REV. 713, 731-32 (2006) (listing California, Connecticut, Louisiana, Maine, Massachusetts, New Jersey, New York, Pennsylvania, and Rhode Island as having enacted moral rights legislation and Utah, Georgia, and Montana as having enacted a more limited form of moral rights legislation).

11. Cal. Civ. Code Ann. § 986 (West 2012); see also Edward J. Damich, Moral Rights Protection and Resale Royalties for Visual Art in the United States: Development and Current Status, 12 CARDOZO ARTS \& ENT. L.J. 387, 405 (stating California is the only state to adopt a law akin to the European resale royalty right); DAVID NIMMER, NIMMER ON COPYRIGHT § 8C.04 (2012); cf. Turner, supra note 7, at 339, n. 57.

12. GA. CODE ANN. $\S 8-5-7$ (West 2012) (providing in relevant part: "If provided by written contract, the right to receive a specified percentage of the proceeds if the work of art is subsequently sold by the state to a third party other than as part of the sale of the building in which the work of art is located. The rights . . may by written contract be extended to such artist's heirs, assigns, or personal representatives until after the end of the twentieth year following the death of such artist. ... Prior to execution of a written contract, the artist shall be informed in writing of the rights . . . which may be granted by contract to the artist or to the artist's heirs, assigns, or personal representatives.") (alterations added); S.D. CODIFIED LAWS $\S 1-22-16(5),(6)$ (West 2012) (providing in relevant part: "If provided by written consent, the right to receive a specified percentage of the proceeds if the work of art is subsequently sold by the state to a third party other than as part of a sale of the building in which the work of art is located; If provided by written consent, the artist's rights may extend to the artist's heirs, assignees, or personal representative until the end of the twentieth year following the death of such artist.").

13. P.R. LAWS ANN. TIT. $31 \S 1401$ (h) (West 2012).

14. See generally Estate of Graham v. Sotheby's Inc., 860 F. Supp. 2 d 1117 (C.D. Cal. 2012). 
District of California in May of 2012. ${ }^{15}$ The court held that the CRRA violated the commerce clause and was unconstitutional on its face because its express language made the law applicable to sales wholly outside of California so long as the owner was a resident of California. ${ }^{16}$ Second, because of a deferment option, the last four member states of the European Union lacking full implementation of the EU directive harmonizing resale royalties for member states completed implementation at the start of 2012. ${ }^{17}$ Third, in December of 2011 identical bills proposing a federal resale royalty right were introduced before the House (H.R. 3688) and the Senate (S. 2000) under the short title "the Equity for Visual Artists Act of 2011 (EVAA)."

Some suggest that the EVAA as introduced goes both too far and not far enough. ${ }^{19}$ An examination of the EVAA in light of prior US efforts and alongside the legislative efforts and experiences of other countries reveals that this statement is an accurate assessment. For instance, the practical experience of other countries sheds light on some problems that spring from resale royalty legislation that the EVAA fails to address. ${ }^{20}$ Yet, the EVAA proposes a complex revenue sharing scheme not yet contemplated by most other countries. ${ }^{21}$ Hence, there is reason to believe that the EVAA as introduced would be ineffective.

Part II of this Note begins with a brief overview of the history of resale royalty legislation. Part III examines the draft EVAA provisions in light of the problems that have been found to exist in designing and implementing resale royalty legislation, and determines whether the EVAA is likely to be effective as written. Part IV addresses how the EVAA might be optimized. Questions concerning the wisdom of adopting federal resale royalty legislation are outside the scope of this Note. ${ }^{22}$ Instead, this Note

15. Id. at $1126-27$.

16. See id. at 1125 .

17. Henry Lydiate, Deceased Artists, ARTQUEST (2008), http://www.artquest.org.uk/ articles/view/deceased-artists 1, archived at http://perma.cc/GQ7T-R7R6.

18. See, e.g., Equity for Visual Artists Act of 2011, H.R. 3688, 112th Cong. (2011) (referred to the subcommittee for Intellectual Property, Competition, and the Internet), archived at http://perma.cc/5HNM-XSEB (THOMAS); see also S. 2000, 112th Cong. (2011), archived at $\mathrm{http}: / /$ perma.cc/Q3F5-Z2GM (THOMAS).

19. Bill Davenport, US Congress Considers Resale Royalties for Visual Artists in New Equity for Visual Artists Act, Glasstire.com (Jan. 3, 2012), http://glasstire.com/ 2012/01/03/us-congress-considers-resale-royalties-for-visual-artists-in-new-equity-forvisual-artists-act/, archived at http://perma.cc/DTS5-QSGH.

20. See infra Part III.A (analyzing how the EVAA handles various recognized problems of resale royalty legislation).

21. See infra Part III (particularly Part III.B.4 and B.14, discussing collection and enforcement under the EVAA).

22. See The Federalist No. 43 (James Madison) (discussing the superiority of federal legislation under the intellectual property clause and the basis for it). "The public good fully coincides in both cases with the claims of individuals." Id. 
focuses on the best way to structure resale royalty legislation in the event it is adopted. Specifically contemplated are the key elements of resale royalty legislation-scope, covered works, minimum price (if any), collection and remittance policy, duration, rate, alienability, waiver, devise, exclusions, formalities, attendant information rights, foreign application, and enforcement. $^{23}$ Notably absent is the issue of the "author." Questions concerning who qualifies as an "author" are generally addressed in a country's primary copyright statute. While some resale royalty legislation might specifically address multiple or corporate authors, these issues are outside the scope of this Note because they are more tangential. This note assumes that in all cases there is one human "author" who might receive a royalty. Further, in order to enhance the usefulness of this article, only free internet sources of international legislation, already translated into the English language or readable via Google Translation and WIPO translation services, were consulted. ${ }^{24}$

\section{THE EVOLUTION OF RESALE ROYALTY LAW}

\section{A. International Origins-History and a Few Examples}

France was the first country to recognize resale royalty legislation because its leaders were moved by public awareness of the plight of artists, who reputedly died in squalor while their works sold for small fortunes to the benefit of others. ${ }^{25}$ The purpose of this legislation was equitable at its core, but economic in effect - it sought to remedy a power imbalance between poor artists and market dealers that allowed dealers to flip paintings, and to address the unfairness of speculation rewarding middlemen and owners whose investment expertise had less to do with increases in value than the artist's creative efforts. ${ }^{26}$

Then, in 1896 a union of countries signed the Berne Convention for the Protection of Literary and Artistic Works (the Berne Convention). ${ }^{27}$ The Berne Convention was revised at Brussels, in 1948, to include Article

23. These are the categories I chose to explore after reading through DE PIERREDONFAWCETT's book and several pieces of legislation. DE PIERREDON-FAWCETT, supra note 7. I consider this list a slight variation upon the categories indicated by de Pierredon-Fawcett in her "Chart of Droit de Suite Laws." DE Pierredon-FAwCett, supra note 7, at 284-91.

24. For more information on my research process, see Elisa Doll, Droit de Suite - An International Comparison, ElisAdolL (Mar. 10, 2013), http://elisadoll.wordpress.com/ 2013/03/10/droit-de-suite-an-international-comparison/, archived at http://perma.cc/P2CYASGX.

25. De Pierredon-Fawcett, supra note 7, at 1-4.

26. De Pierredon-FAwCETt, supra note 7, at 1-4.

27. Berne Convention for the Protection of Literary and Artistic Works, Sept. 9, 1886, as revised at Paris on July 24, 1971 and amended in 1979, S. TREATY Doc. No. 99-27 (1896), archived at http://perma.cc/M4BE-X9QX [hereinafter Berne Convention]. 
14bis, a resale royalty provision. ${ }^{28}$ A later revision at Paris, in 1971, retained the original language but moved the resale royalty provision to Article 14 ter ${ }^{29}$ which provides:

The author, or after his death the persons or institutions authorized by national legislation, shall, with respect to original works of art and original manuscripts of writers and composers, enjoy the inalienable right to an interest in any sale of the work subsequent to the first transfer by the author of the work. ${ }^{30}$

...

The procedure for collection and the amounts shall be matters for determination by national legislation. ${ }^{31}$

The rights conferred under the Berne Convention were extremely vague and largely left to the signatory countries to ferret out. Additionally, the Berne Convention contains a significant limitation- - $[t]$ he protection provided ... may be claimed in a country of the Union only if legislation in the country to which the author belongs so permits, and to the extent permitted by the country where this protection is claimed." ${ }^{\text {, }}$ This provision came to be known as the "principle of reciprocity." Additionally, because adoption of the resale royalty was not made mandatory by the treaty, the royalty could be circumvented. ${ }^{33}$ Other major international treaties adopted since the Berne Convention-namely, the WIPO Copyright Treaty ${ }^{34}$ of 1996, the Agreement on Trade Related Aspects of Intellectual Property Rights (TRIPS) ${ }^{35}$ of 1994, and the Universal Copyright Convention (UCC) $^{36}$ of 1952 (largely superseded by TRIPS) - each adopt portions of the Berne Convention by reference but do not contain separate provisions

28. Berne Convention for the Protection of Literary and Artistic Works, Sept. 9, 1886, as revised at Brussels on June 26, 1948, 331 U.N.T.S. 217 (1896), archived at http://perma.cc/C2NK-C482; see also DE PIERREDON-FAWCETT, supra note 7 and accompanying text.

29. Berne Convention, supra note 27, art. 14ter; see also NIMMER, supra note 11, app. 27.

30. Berne Convention, supra note $27, \S 1$.

31. Berne Convention, supra note $27, \S 3$.

32. Berne Convention, supra note $27, \S 2$.

33. Irma Sirvinskaite, Toward Copyright "Europeanification”: European Union Moral Rights, 3 J. INT'L MEDiA \& ENT. L. 263, 285-86 (2010-2011).

34. WIPO Copyright Treaty art. 1, Dec. 20, 1996, 2186 U.N.T.S. 121, S. TREATY Doc. No. 105-17 (1997), archived at http://perma.cc/X7H9-SGFX.

35. Agreement on Trade-Related Aspects of Intellectual Property Rights, Apr. 15, 1994, Marrakesh Agreement Establishing the World Trade Organization, Annex 1C, 1869 U.N.T.S. 299, 33 I.L.M. 1197 (1994), archived at http://perma.cc/4P29-KT54 (providing in Article 9 for the incorporation of portions of the Berne Convention).

36. De Pierredon-Fawcett, supra note 7, at 101. 
for resale royalties. The following provides a history, as well as some examples, of the ways in which this type of legislation might be drafted.

\section{Resale Royalties in the European Union $(E U)^{37}$}

The resale royalty did not gain significant force until 2001 when the EU adopted a directive harmonizing copyright law among member nations-EU Directive 2001/84/EC. The directive contained a clear statutory purpose:

The resale right is intended to ensure that authors of graphic and plastic works of art share in the economic success of their original works of art. It helps to redress the balance between the economic situation of authors of graphic and plastic works of art and that of other creators who benefit from successive exploitations of their works. ${ }^{38}$

The royalty applies to "all acts of resale involving as sellers, buyers or intermediaries art market professionals, such as salesrooms, art galleries and, in general, any dealers in works of art." 39 It applies to "works of graphic or plastic art such as pictures, collages, paintings, drawings, engravings, prints, lithographs, sculptures, tapestries, ceramics, glassware and photographs ... [that] are made by the artist himself or are copies considered to be original works of art"-termed "original works of art." Also included are copies "made in limited numbers by the artist himself or under his authority" or that are "numbered, signed or otherwise duly authorised by the artist."

37. By "EU” I mean Austria (1995), Belgium (1952), Bulgaria (2007), Cyprus (2004), Czech Republic (2004), Denmark (1973), Estonia (2004), Finland (1995), France (1952), Germany (1952), Greece (1981), Hungary (2004), Ireland (1973), Italy (1952), Latvia (2004), Lithuania (2004), Luxembourg (1952), Malta (2004), Netherlands (1952), Poland (2004), Portugal (1986), Romania (2007), Slovakia (2004), Slovenia (2004), Spain (1986), Sweden (1995), and the United Kingdom (1973). This differs somewhat from the European Economic Trading Area (EEA), which includes the EU members plus Iceland, Liechtenstein, and Norway. See Europa - Countries, EuropA.EU, http://europa.eu/abouteu/countries/index_en.htm (last visited Jan. 7, 2014, archived at http://perma.cc/LXH-34XZ) (listing 27 members and year joined); EEA Agreement, EFTA, http://www.efta.int/eea/eeaagreement.aspx (last visited Jan. 7, 2014, archived at http://perma.cc/AG79-HWPP) (summarizing EEA agreement).

38. Directive 2001/84/EC of the European Parliament and of the Council of 27 September 2001 on the Resale Right for the Benefit of the Author of an Original Work of Art, § (3) pmbl., 2001 O.J. (L 272) 32, archived at http://perma.cc/QD8G-3JQP.

39. Id. art. $1, \S 2$.

40. Id. art. $2, \S 1$.

41. Id. art. $2, \S 2$. 
$3,000,{ }^{42}$ but Member states have the option of adding a further restrictionthat the resale royalty not apply to works sold by owners that were purchased from the author within the past three years, and are sold for less than EUR $10,000 .{ }^{43}$ The seller has to pay the royalty. ${ }^{44}$ However, the EU leaves collection and remittance specifics to Member countries. ${ }^{45}$ The EU duration is the life of the author plus seventy years. ${ }^{46}$ The harmonizing directive provides for a rate schedule:

(a) $4 \%$ for the portion of the sale price up to EUR 50[,]000;

(b) $3 \%$ for the portion of the sale price from EUR 50[,]000[.]01 to EUR 200[,]000;

(c) $1 \%$ for the portion of the sale price from EUR 200[,]000[.]01 to EUR 350[,]000;

(d) $0[] 5 \$.$% for the portion of the sale price from EUR$ $350[] ,000[]$.01 to EUR 500[,] 000;

(e) $0[] 25 \$.$% for the portion of the sale price exceeding$ EUR 500[,]000.

However, the total amount of the royalty may not exceed EUR 12[,]500. ${ }^{47}$

The resale royalty is inalienable. ${ }^{48}$ It is payable to "the author of the work and . . . after his death to those entitled under him/her." ${ }^{49}$ Finally, the EU affords authors a three-year post-sale right to information that can compel "art market professionals" to furnish information necessary to facilitate collection of a resale royalty. ${ }^{50}$

By most accounts the EU legislation has been successful. Reports from London indicate that $£ 15.5$ million have been paid to living artists since 2006. ${ }^{51}$ The European Commission reports that French and German markets all experienced varying degrees of increase in sales between 2010 and 2011. ${ }^{52}$ Additionally, the European Commission reports that the "EU

42. Id. art. $3, \S \S 1-2$.

43. Id. art. $1, \S 3$.

44. Id. art. $1, \S 4$.

45. Id. $\S(28) \mathrm{pmbl}$.

46. Id. $\S(17) \mathrm{pmbl}$.

47. Id. art. $4, \S 1$ (alterations added).

48. Id. art. $1, \S 1$.

49. Id. art. $6, \S 1$.

50. Id. art. 9 .

51. Daniel Grant, 'Droit de Suite' Debate Heats Up, ARTnEws (Jan. 11, 2012), http://www.artnews.com/2012/01/11/droit-de-suite-debate-heats-up/, archived at http://perma.cc/3WYV-C8VH.

52. Submission of Comments For the Equity for Visual Artists Act of 2011 By AKKA/LAA 2 (2012), archived at http://perma.cc/A6HU-JV58 (containing commentary in 
market share in the works of living EU artists has risen from $60 \%$ in 2002 to $66 \%$ in 2010 , and the UK market share from $40 \%$ to $42 \%$." ${ }^{53}$ Importantly, the average estimated cost per transaction was just EUR 50. ${ }^{54}$ Roughly 45 percent of sales fell below the EUR 3,000 tier, garnering royalties of up to EUR 150, and another 39 percent were one bracket higher, earning royalties up to EUR 2,030. ${ }^{55}$

As of 2013, resale royalty legislation exists outside the United States at both regional and national levels. The Member countries of the EU and the European Economic Trading Area (EEA) only account for roughly half of all countries with resale royalty legislation. The Andean Community $(\mathrm{AC})^{56}$ and the Organisation Africaine de la Propriété Intellectuelle $(\mathrm{OAPI})^{57}$ are examples of other regional trade blocs with resale royalty legislation. Individual countries also have adopted national-level legislation, such as Australia ${ }^{58}$ and Brazil. ${ }^{59}$ Over the past two years, Canada ${ }^{60}$ and China ${ }^{61}$ have both considered adopting resale royalty legislation.

\section{Andean Community $(C A N)^{62}$}

The Andean Community's Decision 351 has a structure similar to EU Directive 2001/84/EC. Decision 351 provides a set of minimum guidelines and, at the same time, expressly commands Member countries to fill in the gaps and details accordingly. ${ }^{63}$ However, CAN guidelines are far less

response to Notice, 77 Fed. Reg. 58,175 (Sept. 19, 2012) (notice of inquiry) and Notice, 77 Fed. Reg. 63,342 (Oct. 16, 2012) (extension of comment period)).

53. European COMmission, Report on the ImPlementation AND EFFECT OF the Resale Right Directive (2001/84/EC) 5 (2011), archived at http://perma.cc/W2UP9HLH.

54. Id. at 8. Costs were largely attributed to "staff costs associated with (i) the determination of qualifying artists; (ii) the determination and location of heirs and other right holders (iii) processing omissions and refunds; together with IT system costs." Id.

55. Id. at 10 .

56. See infra Part II.A.2.

57. See infra Part II.A.3.

58. See infra Part II.A.4.

59. See infra Part II.A.5.

60. Contemporary Art Galleries Association, supra note 6.

61. Katie Hunt, China Debates Droit de Suite: Some Say It Will Stifle the Market, Others Think It Could Stop Fakes at Auction, ART NEwSPAPER (Feb. 18, 2013), http://www.theartnewspaper.com/articles/China-debates-droit-de-suite/28565, archived at http://perma.cc/AWN4-8CNQ. For a little more information on this topic see Hong Xue, One Step Ahead, Two Steps Back: Reverse Engineering the Second Draft for the Third Revision of the Chinese Copyright Law, 28 AM. U. INT'L L. REV. 295 (2012) (containing useful sources as well).

62. About Us, COMUNIDAD ANDINA, http://www.comunidadandina.org/ingles/who.htm (last visited Jan. 7, 2014, archived at http://perma.cc/EV4B-T6R4) (listing four Member Countries: Bolivia, Republic of Colombia, Ecuador, Peru).

63. Decisión 351-Régimen Común sobre Derecho de Autor y Derechos Conexos [Decision 351-Common Provisions on Copyright and Neighboring Rights], arts. 12 and 42, 
demanding than those of the European Union. For instance, Decision 351's resale royalty provision simply states that "authors of works of art and, on their death, their successors in title shall have the inalienable right to be granted a share in the successive sales of the work by public auction or through a professional art dealer. The Member Countries shall enact provisions on the said right." ${ }^{, 4}$ Similarly, Member countries must establish duration of no less than the life of the author plus fifty years, ${ }^{65}$ and refrain from adopting formal prerequisites. ${ }^{66}$ Member Countries must determine limitations on transfer or assignment, ${ }^{67}$ and participation in collective administration is voluntary unless a Member Country legislates otherwise. ${ }^{68}$

Because of the relative flexibility of CAN guidelines, there is significant variation in resale royalty legislation across its Members. As of 2011, only one of the four CAN Member Countries has not enacted a resale royalty provision: Colombia. ${ }^{69}$ Bolivia has the oldest statute, and even though it has not been updated substantially as of $2013,{ }^{70}$ its terms are not very different from those of Ecuador ${ }^{71}$ and Peru. ${ }^{72}$ One exception is that the latter two have both adopted longer terms of protection like the European Union-life of the author plus seventy years ${ }^{73}$ - while Bolivia retains life

Dec. 21, 1993 Gaceta Oficial del Acuerdo de Cartagena [Official Gazette of the Cartagena Agreement], X-No. 145, archived at http://perma.cc/5HG4-DRRN (English language translation by the International Bureau of WIPO).

64. Id. art. 16.

65. Id. art. 18.

66. Id. art. 52.

67. Id. art. 30 .

68. Id. art. 44.

69. See generally, L. 23 art. 3, enero 28, 1982, DiARIO OfICIAL [D.O.] (Colom.), archived at http://perma.cc/N73V-EB33 (English language translation). L.23 was amended by L. 44, febrero 5, 1993, DIARIO OFICIAL [D.O.] (Colom.), archived at http://perma.cc/9HJA-EHXU (regarding collecting societies); see also L. 719, diciembre 24, 2001, DiARIO OFICIAL [D.O.] (Colom.) (also regarding collecting societies); L.1403, julio 19, 2010, Diario OfiCIAL [D.O.] (Colom.) (regarding remuneration for performers in images and sounds); L. 1450, junio 16, 2011, DiARIO OFICIAL [D.O.] (Colom.) (implementing National Development Plan: 2010-2014), archived at http://perma.cc/7QLL-MHNZ (unofficial translation by Google Translator); L. 1520, abril 13, 2012, Diario Oficial, [D.O.] (Colom.) (implementing US-Colombia trade agreement for greater trademark protection and anti-piracy provisions).

70. L. 1322, abril 13, 1992, sobre el Derecho el Autor (Bol.), archived at http://perma.cc/P93E-VPKR (English language translation by the International Bureau of WIPO); see also infra Appendix A, Bolivia; but see Sup. Dec. No. $23907 \S \S 1-9$, diciembre 7, 1994, archived at http://perma.cc/U9XA-FGCV (English language translation by the International Bureau of WIPO) (updating rules for collection societies).

71. Codification No. 2006-13 (Supplement to Official Register No. 426, Dec. 28, 2006) (Ecuador), archived at http://perma.cc/W6PW-T6WE (English language translation by the International Bureau of WIPO); see also infra Appendix A, Ecuador.

72. Decreto Legislativo No. 822, abril 24, 1996, Ley Sobre el Derecho de Autor (Peru), archived at http://perma.cc/NQ8M-24XL (English language translation by the International Bureau of WIPO); see also infra Appendix A, Peru.

73. Decreto Legislativo No. 822 art. 52-56 (term of protection). 
plus fifty years. ${ }^{74}$ Second, their royalty rates are not necessarily the same. ${ }^{75}$ Third, all three royalty schemes cover "works of three-dimensional art," but royalties in Bolivia and Ecuador also cover manuscripts. ${ }^{76}$ Similarly, all three schemes exclude from coverage architectural works but differ as to applied art, audiovisual works, and photographs. ${ }^{77}$ Peru is the only Member that has a cultural preserve mechanism-a provision that forwards unclaimed royalties to its National Institute of Culture "for cultural promotion purposes." ${ }^{, 78}$ In spite of these differences, all Members agree that the right is inalienable and cannot be waived; the right may be devised; no formalities are needed for the right to vest; the royalty shall apply to all resale transactions involving a public auction or art dealer; and, that rights holders may entrust their rights to collective management. ${ }^{79}$

On the whole, it seems that the CAN legislation is much less extensive than that of the European Union. The broad grant of Decision 351 leaves much more to its Members than EU Directive 2001/84/EC. There also appears to be slightly less consistency in key provisions across Members; variation exists in roughly half the elements. However, unlike the European Union, there does seem to be a consensus that a flat rate is the best approach despite no guidance as to the optimal rate scheme. ${ }^{80}$ Some scholars suggest, though, that such minimal standards at the regional level were likely the result of a rapid policy change and probably explain a lack of consistency in content and procedure, as well as in transparent legislative process. ${ }^{81}$ Additionally, Decision 351 was unable to eliminate internal

74. Codification No. 2006-13, supra note 71, arts. 80-81 (duration).

75. See L. 1322, supra note 70, art. 50 (noting that Bolivia's rate is five percent of sales price); Codification No. 2006-13, supra note 71, art. 38 (noting that Ecuador's rate is five percent of sales price "unless otherwise agreed"); Decreto Legislativo No. 822, supra note 72 , art. 82 (noting that Peru's rate is three percent of sales price, "it being possible to agree on a different percentage").

76. L. 1322, supra note 70, art. 50; Codification No. 2006-13, supra note 71, art. 38; Decreto Legislativo No. 822, supra note 72, art. 82.

77. L. 1322, supra note 70, arts. 6(j), 50, 51 (noting that Bolivia excludes applied art); Codification No. 2006-13, supra note 71, art. 38 (showing that Ecuador excludes photos and A/V works and doesn't mention applied art in this regard); Decreto Legislativo No. 822, supra note 72, arts. 5(f), 82 (showing that Peru excludes photos and A/V works and specifically includes applied art).

78. Decreto Legislativo No. 822, supra note 72, art. 84 (implementing a three-year limitation on claims from notice of resale).

79. L. 1322, supra note 70, arts. 2, 50, 64; Sup. Dec. No. 23907, supra note 70, § 27(4); Codification No. 2006-13, supra note 71, arts. 5, 38, 109; Decreto Legislativo No. 822, supra note 72 , arts. 3, 82, 147.

80. See infra Appendix A, Belgium, Greece; infra Appendix B (chart indicating that Belgium and Greece apply a flat rate rather than the mandated tiered rate).

81. Alberta J. Cerda Silva, Copyright Convergence in the Andean Community of Nations, 20 Tex. Intell. Prop. L.J. 429, 435-36 (2012) (noting that the European Union has fared much better in these areas). 
market distortions that favored some producers over others and caused unfair advantages among CAN Members. ${ }^{82}$ The light infrastructure might also be a factor in reported enforcement issues. ${ }^{83}$ But that is not to say that the European Union is immune from such internal inconsistencies. Some EU countries also appear to have lagged behind in implementation. ${ }^{84}$

\section{Organisation Africaine de la Propriété Intellectuelle ${ }^{85}$}

The OAPI is an economic trading bloc like the EEA. ${ }^{86}$ The relevant resale legislation provides:

(1) Authors of graphic and three-dimensional works, and of manuscripts, shall have an inalienable right, regardless of any transfer of the original work, to participate in the proceeds of any sale of such work or manuscript by public auction or through a dealer, whatever the conditions under which the transaction was carried out by the latter.

(2) The above provision shall not apply to works of architecture or to works of applied art.

(3) The conditions for exercising such right, as also the rate of participation in the proceeds of sale, shall be determined by the competent national authority. ${ }^{87}$

Information as to the effectiveness of their regional scheme was not readily available. English language translations were available for only half of the member states. ${ }^{88}$ Generally speaking, however, the OAPI has been

82. Id. at 440 .

83. Ronald Kirk, Office of the United States Trade Representative, 2012 SPECIAL 301 REPORT 41-43, 48 (2012), archived at http://perma.cc/L7JU-JT3D (reporting all four members as part of the "watch list" and discussing under each country continuing various problems with enforcement, level of protection, and internet piracy).

84. See, e.g., infra Appendix A, Belgium; infra Appendix B, chart column for Belgium.

85. Member States, OAPI, http://www.oapi.int/index.php/en/aipo/etats-membres (last visited Mar. 9, 2013, archived at http://perma.cc/YTV5-UXM5) (Google Translate) (listing the Republics of Benin, Burkina Faso, Cameroon, Central African Republic, DR Congo, Côte d'Ivoire, Equatorial Guinea, Gabon, Guinea, Guinea-Bissau, Mali, Mauritania, Niger, Senegal, Chad, and Togo).

86. History, OAPI, http://www.oapi.int/index.php/en/aipo/historique (last visited Mar. 9, 2013, archived at http://perma.cc/7KBP-JGF5) (Unofficial Google Translator Translation).

87. Accord portant révision de l'Accord de Bangui du 02 mars 1977 instituant une Organisation Africaine de la Propriété Intellectuelle [Agreement Revising the Bangui Agreement of 02 March 1977 establishing an African Intellectual Property] art. 10, Mar. 2, 1977 (amended Feb. 24, 1999), archived at http://perma.cc/ZCB6-VM4Z (English language translation by the International Bureau of WIPO).

88. See infra Appendix A, Benin, Burkina Faso, Cameroon, DR Congo, Guinea-Bissau, Senegal, Chad, and Togo; infra Appendix B, chart columns for Benin, Burkina Faso, 
recognized as having a good intellectual property framework, despite some enforcement issues. $^{89}$

\section{Australia $^{90}$}

Australia is one example of an individual country that has crafted a national-level resale royalty. It has enacted a detailed, flat-rate royalty scheme that has been largely effective. ${ }^{91}$ Its success might be attributable to its most distinguishing feature-Australian resale royalty legislation is far more centralized than other schemes. ${ }^{92}$ However, many of Australia's key royalty elements are similar to those of the European Union.

In Australia, the royalty applies to each commercial resale of "original work[s] of visual art" ${ }^{, 93}$ that involves an art market professional, ${ }^{94}$ so long as the sales price meets or exceeds AUD $\$ 1,000$ or foreign currency equivalent. ${ }^{95}$ This scheme allows authors to pursue the right on their own or through one government approved collective management entity. ${ }^{96}$ However, authors and their successors must pass a residency test in order to claim the right. ${ }^{97}$ In a position that varies slightly from that of EU or CAN

Cameroon, DR Congo, Guinea-Bissau, Senegal, Chad, and Togo.

89. Make the Most of Africa's IP Organisations, MANAgIng Intellectual Property (Oct. 1, 2009), http://www.managingip.com/Article/2306369/Make-the-most-of-Africas-IPorganisations.html, archived at http://perma.cc/E7GL-3Y58.

90. Resale Royalty Right for Visual Artists Act 2009 (Austl.), archived at http://perma.cc/X7CJ-TNMC.

91. See Resale Royalty, http://www.resaleroyalty.org.au/ (last updated Aug. 8, 2013, archived at http://perma.cc/86GS-89WG). Between its inception in June of 2010 and Jan. 31, 2013, Copyright Agency Ltd. distributed \$1.4 million to more than 530 artists, 85 percent of whom were living and 60 percent of whom were indigenous; and, most royalties paid fell between \$50-500. Id.; see also COPYRIGHT AgENCY LTD. AND VisCOPY, SubMission to US COPyright OfFice ON ARTISTS' Resale RoyAlty Right 4 (2012), archived at http://perma.cc/H66Y-7C37 (commentary in response to Notice, 77 Fed. Reg. 58,175 (Sept. 19, 2012) (notice of inquiry) and Notice, 77 Fed. Reg. 63,342 (Oct. 16, 2012) (extension of comment period)) (characterizing efforts as "successful").

92. COPYRight AGENCY LTD. AND Viscopy, supra note 91 (noting one website that reports auction sales); Resale Royalty Scheme, AtTORNEY GenERAL OF Australia, http://arts.gov.au/visual-arts/resale-royalty-scheme (last visited Oct. 24, 2013, archived at http://perma.cc/PZ2P-FNWW) (noting that Copyright Agency Ltd. is the singular entity appointed by the government to manage resale royalties for a period of five years); Resale Royalty Right for Visual Artists Act 2009, supra note 90, § 35.

93. Resale Royalty Right for Visual Artists Act 2009, supra note 90, §§ 7, 13 (including but not limited to artists' books, batiks, carvings, ceramics, etc.) (alteration added).

94. Resale Royalty Right for Visual Artists Act 2009, supra note 90, $§ 8$ (excluding some transfers per $\S \S 8,9$, and 11 and defining "art market professional" as an auctioneer, owner, or operator of a gallery or museum, art dealer, or other person involved in the business of dealing in artworks).

95. Resale Royalty Right for Visual Artists Act 2009, supra note 90, § 10 (minimum price).

96. Resale Royalty Right for Visual Artists Act 2009, supra note 90, §§ 19-31, 35-38.

97. Resale Royalty Right for Visual Artists Act 2009, supra note 90, § 14 (residency test 
Members, Australia provides that unclaimed funds should first be distributed to any co-authors, then remitted back to the seller, and, if neither is possible, retained to cover administrative costs. ${ }^{98}$ Like the European Union and the majority of CAN, the right is exercisable for the life of the author plus seventy years. ${ }^{99}$ The remuneration rate is 5 percent of the sales price net of buyer's premiums and taxes, except the goods and services tax, or GST. ${ }^{100}$ This differs from the EU royalty which is calculated from the net of all taxes and uses a sliding scale rather than a flat rate. ${ }^{101}$ Similar to EU and CAN royalties, the Australian royalty is considered personal, is absolutely inalienable, and cannot be waived. ${ }^{102}$ These rights may only be devised or descend where a four-pronged succession test is met. ${ }^{103}$

\section{Brazil $^{104}$}

A very different example is found in the country of Brazil. It also employs a national-level resale royalty scheme. Brazil's legislation simply provides that "[t]he author has the irrevocable and inalienable right to collect a minimum of 5 per cent of any gain in value that may be achieved in each resale of an original work of art of [sic] manuscript that he has disposed of." 105 The right is exercisable for the life of the author plus seventy years, ${ }^{106}$ and may be devised per "the order of succession under civil law."107 Additionally, authors may choose to form non-profit organizations for the exercise and defense of their rights. ${ }^{108}$ Either way, "[w] here the author does not collect his resale royalty at the time of the resale, the vendor shall be considered the depositary of the sum payable to him, except where the operation has been conducted by an auctioneer, in

applies to natural and legal persons).

98. Resale Royalty Right for Visual Artists Act 2009, supra note 90, § 31 (return of royalties after 6 years).

99. Resale Royalty Right for Visual Artists Act 2009, supra note 90, § 32 (duration).

100. Resale Royalty Right for Visual Artists Act 2009, supra note 90, $§ 18$ (consideration threshold); see generally GST Overview, Australian TAXATION Office, http://www.ato.gov.au/content/57709.htm (last updated Jul. 24, 2013, archived at http://perma.cc/9M4R-EUJZ) (describing the GST); GST in Australia, My Mother HeN: ChARTERED ACCOUNTANTS, http://www.gstaustralia.com.au/ (last visited Jan. 10, 2014, archived at http://perma.cc/Y345-FKU2) (explaining that the GST is comparable to the European Union's value-added tax, or VAT).

101. See supra Part II.A.1.

102. Resale Royalty Right for Visual Artists Act 2009, supra note 90, §§ 33-34.

103. Resale Royalty Right for Visual Artists Act 2009, supra note 90, $§ 15$.

104. Decreto No. 36, de 19 de Fevereiro de 1998, DiÁRIo Oficial DA União [D.O.U.] de 20192020.2.1998 (Braz.), archived at http://perma.cc/BAZ5-NANN (English language translation by the International Bureau of WIPO).

105. Id. art. 38 (alteration added).

106. Id. arts. 41-45 (duration).

107. Id. art. 41 (succession).

108. Id. arts. 97-100 (collective management). 
which case the latter is considered the depositary." 109

This particular scheme is very shallow and adopts the percentage-ofincrease model that Liliane de Pierredon-Fawcett reported in the early 1990s had proved unworkable because of the complexities and costs associated with tracking both purchase and sale prices. ${ }^{110}$ The insufficiency of Brazil's intellectual property protection generally, relative to other countries, has already been noted. ${ }^{111}$ However, the scheme that Brazil sets out is worth reviewing because it is typical of the way many countries used to structure the right. ${ }^{112}$

\section{B. Prior Resale Royalties in the United States}

\section{Early Federal Efforts}

Resale royalties were advocated in the United States as early as the 1940's by individual authors and creative unions. ${ }^{113}$ But, these movements did not gain traction until the media circulated reports of a public physical altercation between an artist and an art dealer who flipped the artist's work at auction. ${ }^{114}$ After that event, there were three failed attempts at adopting federal resale royalty legislation. ${ }^{115}$ The following provides a history as well as some examples of the ways in which this type of legislation might be drafted.

\section{a. Visual Artist's Residual Rights Act of $1978^{116}$}

This first attempt at crafting a federal resale royalty called for an

109. Id. art. 38 (sole paragraph).

110. De Pierredon-Fawcett, supra note 7, at 12-13, 108-110; see also U.S. Copyright Office, Droit de Suite: The Artist's Resale Royalty xii (1992), archived at http://perma.cc/J4W7-JFSP (noting that successful implementation requires the simple and practical method of taking from the resale price).

111. KIRK, supra note 83, at 41-42 (indicating that amendments are pending but that they could be better; Brazil continues to face problems of enforcement, increasing instances of piracy and counterfeit goods); Marjolein van der Heide, Brazilian Collecting Society ECAD Faces Fraud Charges, Future of Copyright (Feb. 5, 2012), http://www.futureofcopyright.com/home/blog-post/2012/05/02/brazilian-collecting-societyecad-faces-fraud-charges.html, archived at http://perma.cc/Y57S-WFN8.

112. De Pierredon-FAwCETt, supra note 7, at 201-58 (noting twenty out of thirty countries with portion-of-proceeds type legislation - e.g., Chile (1970), Czechoslovakia (1926), Italy and Holy See (1941), Luxembourg (1972), Poland (1935), Uruguay (1938), etc.).

113. Farber, supra note 10, at 724-25.

114. Farber, supra note 10, at 725.

115. See Doll, supra note 24 (comparing US national resale royalty legislative efforts).

116. See generally Visual Artists' Residual Rights Act of 1978, H.R. 11403, 95th Cong. (1987). 
extensive regulatory scheme that included provisions for the creation of a National Commission on the Visual Arts (NCVA) that would administer the Act and promulgate regulations accordingly, and for the establishment of a Visual Arts Fund. ${ }^{117}$

The resale royalty applied to sales of all "work[s] of visual art"118 that were also considered "works of fine art," "119 which were sold in interstate commerce. ${ }^{120}$ The royalty would not apply to works priced less than $\$ 1,000$ or exchanged for goods with a fair market value less than $\$ 1,000$ and that are not visual works of art, or to works resold for less than $105 \%$ of the seller's purchase price. ${ }^{121}$ The royalty rate was 5 percent of the sales price or the fair market value of goods exchanged that were not visual works of art. ${ }^{122}$ After each sale, the seller had thirty days to remit the royalty alongside a statement of the details of the transaction to the NCVA before sanctions could apply. ${ }^{123}$ Information remitted in statements to the NCVA was confidential unless waived in writing or by order of the court for good cause. ${ }^{124}$

The resale royalty duration was life plus the period within fifty years of the author's date of death. Collection of the royalty by the author ${ }^{125}$ was voluntary - it was contingent on the author having registered and filed a written claim with the NCVA, and was limited to a seven-year claim period. ${ }^{126}$ The royalty was inalienable, and authors could not waive or assign their interests, but they could devise them according to a specific order of priority: desired beneficiary, surviving spouse, any surviving legal children, surviving parents, the estate, or according to state intestacy laws. $^{127}$

Additionally, authors reselling their work and dealers making a resale

117. Id. $\S 6$ (directing the NCVA to establish a fund with a "payments" account and an "operations" account).

118. Id. § 2. "The term 'work of visual art' means an original two-dimensional or threedimensional work of art which is a painting, sculpture, drawing, photograph, print, etching, or lithograph. ... [and] does not include any category of items which the [NCVA] shall determine by regulation not to be a category of works of fine art." Id. (emphasis added) (alterations added).

119. Id.

120. Id. § 2(5), 4(a)(1).

121. Id. $\S 4(\mathrm{a}), 4(\mathrm{e})$ (describing minimum price, minimum appreciation in value, and other exclusions).

122. Id. $\S 4$ (a) (also fair market values were subject to NCVA review).

123. Id. $\S 4(\mathrm{~d})$ (indicating that should a seller fail to submit the royalty or statements, the NCVA could bring an action to enforce within the three-year period following the sale date, or within the one-year period following notice of a sale, whichever occurs last).

124. Id. $\S 3(\mathrm{k})$.

125. See id. §5(b), 4(e)(3) (giving special treatment to disbursement of royalties to joint authors and authors of commissioned works).

126. Id. § 5(c), (d).

127. Id. $\S 5(\mathrm{f})$. 
within two years of the purchase date were excluded from the royalty. ${ }^{128}$ Finally, art work integrated with a permanent structure and sold as part of the structure was also excluded. ${ }^{129}$

\section{b. Visual Artists Rights Amendment of $1986^{130}$}

This legislation would have added a resale royalty as an exclusive right under section 106 of the Copyright Act. ${ }^{131}$ The purpose of this legislation was "to provide for resale royalties" and other moral rights. ${ }^{132}$ The resale royalty provision applied to each sale after the initial sale by the artist. ${ }^{133}$ It covered "pictorial, graphic, or sculptural works." 134 There was a minimum price as well - a "gross sales price" of " $\$ 500$ " or an "exchange for property with a fair market value" of " $\$ 500$ " so long as the seller received at least " 140 percent of the purchase price paid by the seller." 135 The seller was required to "pay to the artist or to the artist's agent ... [or] to the National Endowment for the Arts for use in the visual arts program."136 The duration was the artist's life plus "fifty years after his death." 137

The royalty rate was "7 percent of the difference between the seller's purchase price and the sale price or the fair market value of any property received in exchange for the work." ${ }^{\prime 138}$ The royalty could not be waived ${ }^{139}$ or devised or descend. ${ }^{140}$ However, the royalty might be assigned during the author's lifetime so long as the assignment did not, in effect, constitute a prohibited waiver. ${ }^{141}$ Hence, the powers of assignment were available but limited. Finally, registration was required for the copyrighted work and for

128. $I d . \S 5(\mathrm{e})$.

129. Id.

130. See generally Visual Artists Rights Amendment of 1986, S. 2796, 99th Cong. (1986).

131. Id. § 3(d)(1); see also H.R. 5722, 99th Cong. (1986) (identical); see generally Copyright Act of 1976, 17 U.S.C.A. $§ 106$ (West 2012) (providing copyright owners with certain exclusive rights).

132. S. 2796 at $\S 3(d)(1)$.

133. Id.

134. Id.

135. Id.

136. Id.

137. S. 2796 at $\S 3(d)(1)$.

138. Id.

139. Id.

140. Id. (" $[\mathrm{W}]$ here the artist is deceased at the time of the sale, and the sale occurs within fifty years . . . royalty shall be paid to the National Endowment for the arts . . ..") (alterations added).

141. Id. ("An artist may assign the right ... provided however, such assignment shall not have the effect of creating a [prohibited] waiver . . ..") (alterations added); see also S. 2796 at $\S 3(d)(1)$. This also suggests a further limitation on assignments - that they terminate with the author's death. 
the sale or transfer subject to the royalty. ${ }^{142}$

$$
\text { c. Visual Artists Rights Act of } 1987^{143}
$$

This version only differed in some regards from the 1986 legislation. The minimum price was a "gross sales price" of $\$ 1,000$ or an "exchange for property with a fair market value" of $\$ 1,000$ so long as the seller received at least " 150 percent of the purchase price paid by the purchaser." 144 The royalty rate was "7 percent of the difference between the seller's purchase price and the amount the seller receive[d] in exchange for the work." 145 The royalty did not apply to works made for hire. ${ }^{146}$ The seller was required to pay "to the author . . . [or] to the estate of the author." 147 Since the royalty could go to the estate it is likely that it was devisable or descendible in some fashion, unlike the 1986 version. But similar to the 1986 version, the right could not be waived but the author was free to assign it provided the assignment did not constitute a prohibited waiver. ${ }^{148}$ Registration was required for the copyrighted work and for the sale or transfer subject to the royalty within ninety days of the transaction. ${ }^{149}$

$$
\text { d. Visual Artists Rights Act of } 1990(\text { VARA) })^{150}
$$

There were five versions of VARA, ${ }^{151}$ but none of them contained a separate provision granting resale royalty rights. Instead, the final bill enacted directed the Copyright Office to conduct a study to determine the feasibility of implementing a resale royalty right. ${ }^{152}$

142. Visual Artists Rights Amendment of 1986, S. 2796, 99th Cong. § 3 (1986).

143. See generally Visual Artists Rights Act of 1987, H.R. 3221, 100th Cong. (1987).

144. Id. $\S 3(\mathrm{~d})(2)$. For example, an author sells a work of fine art to a purchaser for $\$ 10$. The purchaser then sells the same work to a buyer. If the purchaser-seller sells the work for $\$ 12$ there is no royalty. If the work sells for $\$ 16$ the royalty would apply. Instead of a minimum price, the statute looks to a minimum percentage gain in value, comparing purchase price to sales price, to determine whether to apply the royalty.

145. Id. $\S 3(\mathrm{~d})(2)$ (alteration added).

146. Id. $\S 8$.

147. Id. $\S 3(\mathrm{~d})(1)$. ("[W]here the author is deceased at the time of the sale, and the sale occurs within fifty years ... royalty shall be paid to the estate of the author . . ..") (alterations added).

148. Id.

149. Id. $\S 3(\mathrm{~d})(2)$.

150. Visual Artists Rights Act of 1990, 17 U.S.C. $§ 106$ A (2012).

151. See generally Visual Artists Rights Act of 1990, H.R. 2690, 101st Cong. (1990), archived at http://perma.cc/5UP4-NWYY.

152. Id. $\S 8(\mathrm{~b})$; see generally U.S. COPYRIGHT OFFICE, supra note 110 . This report essentially concludes that there was not enough empirical evidence as to the effectiveness of the various efforts in practice, that more study is needed, and that the issue should be revisited once Europe has harmonized. U.S. COPYRIGHT OFFICE, supra note 110, at Xv-xvi. 


\section{State and Territory Efforts}

While federal efforts failed to bear fruit, other portions of the United States were able to put forth resale royalty legislation. Two entitiesCalifornia and Puerto Rico - enacted statutes crafted like those already in place internationally.

\section{a. California}

The resale royalty applies "[w]henever a work of fine art is sold and the seller resides in California or the sale takes place in California."153 "Fine art" means "an original painting, sculpture, or drawing, or an original work of art in glass." 154

The royalty does not apply to works sold for less than $\$ 1,000$, or to barters or combined property and cash barters where the value of the exchange is less than $\$ 1,000 .^{155}$ The seller or the seller's agent pays the artist, or if unable to locate the artist within ninety days, the California Arts Council. ${ }^{156}$ The royalty is payable for the life of the artist plus twenty years. ${ }^{157}$ The rate is a flat 5 percent of the sales price. ${ }^{158}$ The royalty right may be waived

only by a contract in writing providing for an amount in excess of 5 percent of the amount of such sale. An artist may assign the right to collect the royalty payment provided by this section to another individual or entity. However, the assignment shall not have the effect of creating a waiver prohibited by this subdivision. ${ }^{159}$

An artist may devise his right to collect royalties to her "heirs, legatees, or personal representative." ${ }^{, 160}$ However, works of fine art resold within ten years strictly between dealers, and works of stained glass artistry permanently affixed to real property and sold as part of the real property are excluded from the royalty. ${ }^{161}$

153. CAL. Civ. CodE $\S 986($ a) (West 2012).

154. Id. $\S 986(\mathrm{c})(2)$.

155. Id. $\S 986(\mathrm{~b})(2),(5)$.

156. Id. $\S 986(\mathrm{a})$.

157. Id. $\S 986(\mathrm{a})(7)$.

158. Id. $\S 986(\mathrm{a})$.

159. Id.

160. Id. $\S 986(\mathrm{a})(7)$.

161. Id. $\S 986(\mathrm{~b})(6),(7)$. 


\section{b. Puerto Rico}

The Puerto Rican resale royalty statute is very brief, but presents a different perspective from the California and proposed federal statutes:

Any person who creates a work of art is entitled to receive five (5) percent of the increase in the value of said work at the moment it is resold. Said amount shall be deducted from the seller's earnings and his/her agent or proxy shall be jointly responsible for that amount. In those cases in which the whereabouts of the author are not known, the resulting amount shall be deposited in his/her name in a special account to be opened by Copyright Registrar. ${ }^{162}$

Hence, the Puerto Rican statute applies only to works whose value appreciates. ${ }^{163}$

\section{THE EQUITY FOR VISUAL ARTISTS ACT OF 2011 (EVAA) ${ }^{164}$}

Like prior efforts, this legislation would add a resale royalty as an exclusive right under section 106 of the Copyright Act. ${ }^{165}$ The Act does not contain a statement of purpose. ${ }^{166}$ The resale royalty applies " $[\mathrm{w}]$ henever a work of visual art is sold as the result of auction of that work by someone other than the artist who is the author of the work." 167 A "work of visual art" means:

(1) a painting, drawing, print, sculpture, or photograph, existing either in the original embodiment or in a limited edition of 200 copies or fewer that bear the signature or other identifying mark of the author and are consecutively numbered by the author, or, in the case of a sculpture in multiple cast, carved, or fabricated sculptures of 200 or fewer that are consecutively numbered by the author and bear the signature or other identifying mark of the

162. P.R. LAWS ANN. TIT. 31, § 1401(h) (2012).

163. See generally DE PIERREdon-FAwCETT, supra note 7 , at 5 (noting that the appreciation in value method typically failed because of the complexity of tracking and remitting along the chain of sales).

164. See generally Equity for Visual Artists Act of 2011, H.R. 3688, 112th Cong. (2011).

165. Id. $\S 3(2)$.

166. See generally id.

167. Id. $\S 3(2)$ (alteration added). 
author. ${ }^{168}$

The term "auction" means "a public sale run by an entity that sells to the highest bidder works of visual art in which the cumulative amount of such works sold during the previous year is more than $\$ 25,000,000$ and does not solely conduct the sale ... on the Internet,"169 and "sale" means a "transfer of ownership or physical possession of a work as the result of the auction of that work."

The resale royalty "shall not apply to the sale of a work for a gross sales price of less than $\$ 10,000$, or in exchange for property with a fair market value of less than $\$ 10,000 . " 171$ The selling entity must remit payment to a collecting society within ninety days. ${ }^{172}$ The Act does not explicitly state the relevant duration, but because the right was added as a Section 106 right, presumably the duration is the same as the other rights: life plus seventy years. ${ }^{173}$ The royalty is 7 percent of the price. ${ }^{174}$ Price means "the aggregate of all installments paid in cash or in-kind by or on behalf of a purchaser for a work as the result of auction of that work." 175 However, the visual artist will realize no more than 3.5 percent:

$[\mathrm{N}] \mathrm{o}$ fewer than 4 times per year, [a collecting society will distribute] 50 percent of the net royalty to the artist or his or her successor as copyright owner. After payment to the artist or his or her successor as copyright owner, the remaining 50 percent of the net royalty shall be deposited into an escrow account established by the collecting society for the purposes of funding purchases by nonprofit art museums in the United States of works of visual art authored by living artists domiciled in the United States."176

The term "net royalty" means "the royalty amount collected less administrative expenses of the visual artists' collecting society. In no case shall the administrative expenses of the visual artists' collecting society subtracted from the royalty amount collected exceed 18 percent."

168. Id. $\S 2(5)$ (amending the definition of "works of visual art" in 17 U.S.C. $\S 101$ to include photographs).

169. Id. § 2(1) (amending 17 U.S.C. § 101 to add "auction").

170. Id. $\S 2$ (1) (amending 17 U.S.C. $\$ 101$ to add "sale").

171. Id. §3(2).

172. $I d$.

173. 17 U.S.C. $\S \S 302-05$.

174. H.R. $3688 \S 3(2)$.

175. Id. $\S 2$ (2) (amending 17 U.S.C. $\S 101$ to include a new definition).

176. Id. § 3(2) (alterations added).

177. Id. 
Additionally, the Copyright Office may deduct up to 5 percent of annual collections prior to the deduction of collecting society fees. ${ }^{178}$ Both the right to receive a royalty and the obligation to deposit in escrow may not be waived. ${ }^{179}$ The Copyright Office is charged with administering the statute. ${ }^{180}$

At the outset, then, US-proposed statutes were very detailed, complex schemes. Later versions were severely stripped down. The most recent version, the EVAA, presents a sort of middle ground.

\section{A. How the EVAA Handles the Recognized Problems of Resale Royalty Legislation}

It is important to recognize at the outset that no single law can anticipate every possible factual situation. Legal professionals learn early in their education that this is what makes writing and administering laws so difficult, and what ultimately generates case law. The experience of other countries has highlighted several fact situations common to resale royalty legislation which might be useful in crafting a US version. Curiously, the EVAA addresses only some of these concerns, causing some commentators to report that the law, as introduced, goes both too far and not far enough. ${ }^{181}$

\section{Problems of Market Efficiency}

Differences in copyright coverage can impede the proper functioning of the market. ${ }^{182}$ If a resale royalty encumbers future sales, patterns of demand, pricing, and velocity may be affected. ${ }^{183}$ Some scholars argue that dealers and galleries have fixed costs to consider and would have to decrease purchase prices on the front end to handle the higher cost to them on the back end. ${ }^{184}$ If visual artists are unwilling to lower prices, ${ }^{185}$ then

178. Id. $\S 6$.

179. Id. $\S 3(2)$.

180. Id. $\S 5$.

181. See Bill Davenport, supra note 19 and accompanying text.

182. Silva, supra note 81, at 433 (examining copyright unity in the Andean Community); see also Council Directive 2001/84, §14, 2001 O.J. (L 272) 37 (EC) (discussing how differences in national resale right provisions impeded proper market functioning within the $\mathrm{EU})$.

183. Elliot C. Alderman, Resale Royalties in the United States for Fine Visual Artists: An Alien Concept, 40 J. Copyright Soc'y U.S.A. 265, 279-80 (1992).

184. Eden, supra note 7, at 155-57.

185. See Maryam Dilmaghani \& Jim Engle-Warnick, The Efficiency of Droit de Suite: An Experimental Assessment, 9 REV. Of ECON. RES. ON COPYRIGHT Issues 93, 102-103, 117 118 (2012) (phrasing the analysis in terms of the artist's willingness to accept, or WTA, the investor's price; while not specifically stated, if artists are unwilling to fully discount the initial price to off-set the future earnings attributable to resale royalties, then basic economics suggests that investors would be less likely to demand works because a higher 
purchase demand could be impacted. Hence, scholars have argued that velocity is much more likely to be affected than previously thought. ${ }^{186}$

Additionally, some fear that imposition of a resale royalty could cause market flight to areas where the right is legally the least burdensome, ${ }^{187}$ or drive sales into the private sector. ${ }^{188}$ This forum shopping might also occur at a national level if states are allowed to retain or promulgate their own resale royalty statutes. ${ }^{189}$ Similarly, sham sales may occur. Sham sales involve moving sales outside areas where the right applies in contravention of the law to avoid paying the royalty that is owed. ${ }^{190}$

However, the practical experiences of many countries that have implemented a resale royalty debunk these concerns. First, many factors determine the location of a market-geographic proximity, public taste, market size or structure, tradition, the presence of experts, the expertise and proactivity of operators, legislation, taxes, etc. ${ }^{191}$ The art market began in Europe and progressed to other areas as the demand for luxury goods grew. ${ }^{192}$ Globalization of markets has also had a hand in opening up markets in China, Russia, and India. ${ }^{193}$ In 2011, European reports indicated that the arts markets in the United States and Switzerland declined while the markets in the United Kingdom, France, and Germany expanded ${ }^{194}$ - the

WTA means a higher price); see also Shane Ferro, What Would Importing Droit de Suite to the U.S. Mean for the Art Market?, ArtInfo.com (Aug. 5, 2011), http://www.artinfo.com/news/story/38274/what-would-importing-droit-de-suite-to-the-usmean-for-the-art-market, archived at http://perma.cc/6QUS-UVQV (noting that resale royalty legislation may decrease demand for art generally).

186. Dilmaghani \& Engle-Warnick, supra note 185, at 117.

187. See Eden supra note 7, at 151-53.

188. Benjamin C. Fishman \& Jo Backer Laird, Artist Resale Royalties in America: California Law Struck Down. National Legislation Proposed, LeXology (Aug. 28, 2012), http://www.lexology.com/library/detail.aspx?g=75a56f7b-a942-4abb-b5bb-1abe3d2868f9, archived at http://perma.cc/9WFN-6Z6J (asserting that resale royalty legislation will "chase more sales out of public view").

189. Mara Grumbo, Note, Accepting Droit de Suite as an Equal and Fair Measure Under Intellectual Property Law and Contemplation of its Implication in the United States Post Passage of the EU Directive, 30 Hastings COMm. \& EnT L.J. 357, 361-75 (2008).

190. See Eden, supra note 7, at 146; see also U.S. COPYRIGHT OfFICE, supra note 110, at xiv.

191. European Grouping of Societies of Authors and Composers, Notice of INQUiRy ON RESALE RoyAlty Right GESAC COMMENTS (GESAC) 2 (2012) (commentary in response to Notice, 77 Fed. Reg. 58,175 (Sept. 19, 2012) (notice of inquiry) and Notice, 77 Fed. Reg. 63,342 (Oct. 16, 2012) (extension of comment period)), archived at http://perma.cc/4VWR-6ZFA.

192. Id.

193. Id.

194. European Visual Artists (EVA), Submission of Comments For the Equity for Visual Artists Act of 2011 by EVA (European Visual Artists) 3 (2012) (commentary in response to Notice, 77 Fed. Reg. 58,175 (Sept. 19, 2012) (notice of inquiry) and Notice, 77 Fed. Reg. 63,342 (Oct. 16, 2012) (extension of comment period)), archived at http://perma.cc/K92C-M6S6 (citing European Commission 2011 Report, archived at 
very opposite of what should have happened, had forum shopping actually occurred. Similarly, growth of the arts market in China was likely due to a general rise in disposable income rather than any forum shopping. ${ }^{195}$ It would seem that as long as the collection rate is no higher than other transactional costs, the market has been shown to absorb them. ${ }^{196}$ The EVAA employs a 7 percent rate, an amount less than standard auction house fees, ${ }^{197}$ and not much different from taxes. ${ }^{198}$ Therefore, the EVAA is not likely to cause any significant forum shopping or sham sales.

\section{Problems of Doctrinal Conflict}

When the legal basis for a statute is unclear, the public may criticize the law and fail to take it seriously. ${ }^{199}$ One legal basis on which the resale right might be predicated is that of unjust enrichment. Under this precept, a subsequent owner is unjustly enriched by increases in value which cannot be attributed in any major way to the actions or abilities of the owner, but can reasonably be attributed to the artist "whose efforts and increasing popularity have had an appreciable impact." 200

Alternatively, the legal basis might be conceived as one of "just desserts" or "participation of the author" in the exploitation of the author's works. Because of factual differences in methods of creating, authors of graphic and plastic works can neither fully participate in the reproductive right nor leverage the distribution right to the same extent as writers and

http://perma.cc/YJF2-MDBE).

195. Id. at 3-4; see also SARAh Thornton, Seven Days in the Art World xvi (2009) (noting that art is popularly considered a luxury good or a status symbol).

196. Eden, supra note 7, at 149-50, 157 (noting fees including a ten to twenty-percent buyer's premium on top of a ten to twenty-percent auction house commission); Shira Perlmutter, Resale Royalties for Artists: An Analysis of the Register of Copyrights' Report, 40 J. COPYRIGHT SOC'Y U.S.A. 284, 298 (1992-1993) (predicting this effect).

197. Eden, supra note 7, at 157.

198. Ferro, supra note 185 (referring to the royalty as a "tax"); see also Letter from Derek Wilson, (commentary in response to Notice, 77 Fed. Reg. 58,175 (Sept. 19, 2012) (notice of inquiry) and Notice, 77 Fed. Reg. 63,342 (Oct. 16, 2012) (extension of comment period)), archived at http://perma.cc/5BGU-UC65 ("For any gains in art sales, collectors already pay a $28 \%$ cap gains, a (soon) $3.8 \%$ healthcare tax and roughly a $10 \%$ commission to sell. So they are already paying $42 \%$ in selling costs."); Alex Rogers, 5 New Obamacare Taxes Coming in 2013, Time (Dec. 7, 2012), http://swampland.time.com/2012/12/07/5-newobamacare-taxes-coming-in-2013/, archived at http://perma.cc/ATQ2-F5PX (confirming $3.8 \%$ capital gains tax increase for 2013).

199. See, e.g., Alexander Bussey, Equity for Visual Artists Act 2011, AleXANDERKAIM BLOG (Dec. 22, 2011, 7:25 AM), http://alexanderkaim.blogspot.com/2011/12/equity-forvisual-artists-act-2011.html, archived at http://perma.cc/ZLD5-MZWP (suggesting the law would not do what it sets out to do); see also W.W. Kowalski, A Comparative Law Analysis of the Retained Rights of Artists, 38 VAND. J. TRANSNAT'L L. 1141, 1173 (2005) (noting that a common problem of droit de suite legislation is that its statutory form sometimes contradicts its essence).

200. De Pierredon-FAwCEtt, supra note 7, at 13. 
composers, which suggests an inequity that needs to be addressed. ${ }^{201}$ Accordingly, the just reward theory that sometimes underpins moral rights legislation generally ${ }^{202}$ can also be the basis for a resale royalty because it asks: "[A]re not visual artists just as deserving of royalties for their creative efforts as writers and composers?"

Others contemplate a more cynical view - that capitalists benefit from intellectual property rights, which serve as a basis for economic power. ${ }^{203}$ Laws which protect intellectual property commoditize it and perhaps falsely assume that some sort of equilibrium is achievable. ${ }^{204}$ Related is the idea that dominant ideas are those of the ruling class. ${ }^{205}$ Combined, these statements flag the need for legislation to find an equilibrium which is likely shifted more towards those who have the economic power: art market professionals. ${ }^{206}$ However, this view might not reflect the realities of the art market. $^{207}$

Also, because resale royalties are arguably moral in character, there is some latitude for a natural rights or personality foundation. This view derives from Lockean theory of property in one's own person-that a man is entitled to "the Labour of his Body," "the Work of his Hands." 208 Related is the idea that the artist's work is an extension of the artist's personality. This view holds that everyone is entitled to claim protection for his or her personality and anything that flows from it. ${ }^{209}$ However, the former view, at least, is not a good fit for the United States, which has disavowed that the

201. De Pierredon-FAwCETt, supra note 7, at 17-20 (noting that such inequities are not new, that drafts for popular reform in the early 1900's frequently contained the slogan "le droit d'auteur aux artistes" (author's rights for artists), and that participation in each sales price is appropriate; explaining further that the factual differences between types of authors is exacerbated by technologies which allow writers and composers to produce works on a near mass scale).

202. Stokes, supra note 4, at 15. But see Stokes, supra note 4, at 15-16, 16 n.22 (indicating that the problem with the just rewards theory is determining how much or how little reward is sufficient under the circumstances).

203. See Ronald V. Bettig, Copyright and the Commodification of Culture, 50 MEDIA DEVELOPMENT 3 (2003).

204. Id.

205. Roderick T. Long, Can We Escape the Ruling Class?, Formulations (1994), archived at $\mathrm{http}: / /$ perma.cc/J2TJ-HPSK.

206. THORNTON, supra note 195, at xii (noting the art world is about control mediated by trust; it is a "statusphere;" great art does not arise, it is made). Artists who aren't institutionalized risk being shut-out. THORNTON, supra note 195, at 118.

207. Lindsay Sullivan, SUITE AND SOUR: An Analysis of the Legal and Economic Woes of The Droit De Suite (2010) (unpublished M.B.A. thesis) (on file with Sotheby's Institute of Art - New York). (Sullivan indicates that this view is probably antiquated and has a tendency to paint art market professionals as villains). Id. at 19-20.

208. See StOKes, supra note 4, at 17-21.

209. StOKes, supra note 4, at 19. But see StOKes, supra note 4, at 20-21 (discussing the problems of natural rights and personality theories - namely, how much effort is to be rewarded, and that creations derive from much more than just the artist's personality). 
"sweat of the brow" doctrine has a place in US copyright law. ${ }^{210}$ Viewing the right as attached to the author somehow, as an extension of himself so to speak, might work as the United States has already done this to some extent with VARA. ${ }^{211}$

Most countries structure the resale royalty right as an economic right, ${ }^{212}$ but espouse some sort of equitable purpose. ${ }^{213}$ This is the problematic dual nature that spurs many arguments ${ }^{214}$ over the benefits of such a right. But, scholars remind us that the point is not to give artists a piece of economic pie, but to recognize certain types of art as a special kind of property important enough in our culture due to its uniqueness that we should create laws which favor a certain kind of exploitation-namely, purchase by museums or other institutions where many people can benefit from viewing the objects. ${ }^{215}$ It is not about economics, but exploitation. Hence, some countries refer to the royalty as a remuneration right. ${ }^{216}$ Structuring the royalty as a right reminds people that the object and the rights are distinct, that it is a right tied to the artist, not the object.

All of these doctrines are dancing around the idea of "purpose." As stated above, when the purpose and the effect of the statute mismatch, the statute may engender criticism. ${ }^{217}$ Is the right meant to aid visual artists new to the market, or to help visual artists more generally? How the right is framed matters. ${ }^{218}$ The EVAA does not include any mention of a purpose apart from its long title. ${ }^{219}$ This concern might be remedied with the inclusion of express language that states the purpose in clear terms.

\section{Problems of Statutory/Tradition Conflict}

At first blush, the first-sale right granted under US copyright law

210. See Feist Publ'ns, Inc. v. Rural Tel. Serv. Co., 499 U.S. 340 (1991). "The "sweat of the brow' doctrine had numerous flaws, the most glaring being that it extended copyright protection in a compilation beyond selection and arrangement-the compiler's original contributions-to the facts themselves. . . . Without a doubt, the 'sweat of the brow' doctrine flouted basic copyright principles. ... [T]he 1976 revisions to the Copyright Act leave no doubt that originality, not 'sweat of the brow,' is the touchstone of copyright protection ..." $i d$. at $353,354,359-60$ (alterations added).

211. Visual Artists Rights Act of 1990, H.R. 2690, 101st Cong. § 3 (1990).

212. See, e.g., infra Appendix A, Spain, Sweden; infra Appendix B, chart columns for Spain, Sweden.

213. See, e.g., 2001/84/EC §§ (3), (4), (11) (pmbl.).

214. STOKES, supra note 4, at 97.

215. Eden, supra note 7, at 124-25 (citing DE PIERREDON-FAWCETT, supra note 7, at 19); see also DE Pierredon-FAwCetT supra note 7, at 19-20 (citing Abel Ferry and talking about participation in exploitation versus participation in speculation).

216. See, e.g., infra Appendix A, Estonia; infra Appendix B, chart column for Estonia.

217. See supra Part III.A.2.

218. Alderman, supra note 183, at 278-79.

219. Equity for Visual Artists Act of 2011, H.R. 3688, 112th Cong. (2011). 
seems incompatible with resale royalty legislation:

Notwithstanding the provisions of section 106(3) [17 USCS sec. 106(3)], the owner of a particular copy or phonorecord lawfully made under this title [17 USCS secs. 101 et seq.], or any person authorized by such owner, is entitled, without the authority of the copyright owner, to sell or otherwise dispose of the possession of that copy or phonorecord. ${ }^{220}$

Indeed, scholars argue that resale rights are in direct conflict with well-settled first-sale principles. ${ }^{221}$ Some academics suggest that the firstsale doctrine cannot exist simultaneously with a resale royalty right. ${ }^{222}$ However, the first-sale doctrine exhausts the copyright interest owner's exclusive distribution rights and in so doing increases competition by allowing for parallel importation and a secondary market. ${ }^{223}$ Resale royalties characterized as moral rights or other express intangible rights are easily distinguished because they attach to the person, not the tangible item that is the subject of a resale transaction. ${ }^{224}$ The limited moral rights already adopted by the United States are illustrative. ${ }^{225}$ Without consideration for the principle that the material object and the author's rights are distinct, these rights appear to conflict with the first-sale doctrine. ${ }^{226}$ The EVAA as introduced would slightly restructure the Section 106 exclusive rights of the Copyright Act such that the traditional six would fall under prong "(a)" and the EVAA would fall under "(b)." 227 This separation is useful, but it might not be enough since it would still fall under the preamble which reads "[s]ubject to sections 107 through $122 \ldots$. ..,228 Thus it does little to relieve the confusion over Section 109's first-sale doctrine. The bill should make a provision for a positive statement within Section 109 that it is applicable only to the distribution right, and not to the resale royalty right.

Closely related to the first-sale doctrine is the principle of free-

220. 17 U.S.C. $\$ 109$ (a) (2012).

221. Benjamin S. Hayes, Integrating Moral Rights Into U.S. Law and the Problem of the Works for Hire Doctrine, 61 OHIO ST. L. J. 1013, 1022 (2000).

222. See Alderman, supra note 183, at 279.

223. Silva, supra note 81 , at 446-47 (noting the US first sale doctrine while discussing how to achieve a common market between nations).

224. See 17 U.S.C. $\S 202$ (2012) (stating that ownership of rights is not the same thing as ownership of a material object).

225. 17 U.S.C. $§ 106 A(a)(3)$ (2012) (codifying VARA's right of integrity- stating that an author may prevent the intentional distortion, mutilation, or other modification of the author's work, or prevent intentional or grossly negligent destruction of the author's work if it is of "recognized stature").

226. Id. VARA rights are not the only ones which appear to conflict with the first sale provision. For further information see John Wiley \& Sons, Inc. v. Supap Kirtsaeng, 654 F.3d 210, 218 (2d Cir. 2011), archived at http://perma.cc/542J-XTAZ; Sebastian Int'l, Inc. v. Consumer Contacts (PTY) Ltd., 847 F.2d 1093, 1097, 1099 (3rd Cir. 1988), archived at http://perma.cc/LF7L-KUYR.

227. Equity for Visual Artists Act of 2011, H.R. 3688, 112th Cong. § 3(1)-(2) (2011).

228. Id. § 3(1) (alteration added). 
alienation; the United States, like many common law countries, has a strong tradition of free alienability of tangible property. Some argue that to the extent that the imposition of a duty to share the receipts of a future resale operates as a disincentive to market visual works of art, it may violate this principle. ${ }^{229}$ However, where this contention is aimed at the material object, it is, essentially, a straw $\operatorname{man}^{230}$ because the author has no control over what happens to the material object he created beyond the first sale. But, where this contention is aimed at the author's bundle of rights, a real concern may exist. $^{231}$ Other economic intellectual property rights are typically freely transferrable, and sequestering the royalty may impinge on the freedom to contract. $^{232}$ However, this restriction is usually not an oversight or unintended effect; if this right were freely alienable, the purpose of this type of legislation as it is generally iterated - to participate in future proceedswould likely be undermined by the ability to contract. ${ }^{233}$ This is a real concern given differences in the level of sophistication between the bargaining parties and the relatively unregulated nature of the arts market. ${ }^{234}$ This is perhaps why so few countries allow this right to be

229. Turner, supra note 7, at 346-47 (noting this popular argument); Kuno Fischer, Switzerland without Resale Right (Droit de Suite): Supplementary Paper Based on Practical Experience, 3/4 JOURNAL KUNST UND RECHT [KUR] (2008), (Ger.), archived at http://perma.cc/GUY4-XXTL (suggesting inalienability requirement is meant to secure a certain volume of business to collective management entities).

230. Design And ARtists Copyright Society, DACS Response to the InQuiRy into the Resale Royalty Right by the U.S. Copyright OfFice 2 (2012) (commentary in response to Notice, 77 Fed. Reg. 58,175 (Sept. 19, 2012) (notice of inquiry) and Notice, 77 Fed. Reg. 63,342 (Oct. 16, 2012) (extension of comment period)), archived at http://perma.cc/WSZ7-446A.

231. De Pierredon-FAwCett, supra note 7, at 33-35 (discussing the basis of this requirement as treating unequal bargaining power between artists and art market professionals and suggesting that this requirement is a substantial restriction precisely because it lacks a true protective purpose).

232. Sullivan, supra note 207, at 31-32.

233. U.S. Copyright Office, supra note 110, at ix. See also Nicholas L. Georgakopoulos, Principles and Methods of Law and Economics: Basic Tools FOR Normative ReAsoning 95-126 (2005) (discussing Coasean irrelevance theorem particularly, the suggestion that if the reaction to a judicial opinion would cancel the effect of that opinion, then the law is irrelevant. At a very basic level, the argument makes sense. Art market professionals would not want the cost of the royalty later on (they are harmed by the amount they have to pay)). Artists want the right and would be harmed by the loss of the right; but, the harm to the artist is less since the royalty is not certain. Professionals would want artists to transfer that right to them, and artists would do so if the professional offered a certain sum now that was at least enough to off-set the loss of the possible future royalty. Hence, the law would be pointless. Obviously, it is more complex than that because the difference in relative bargaining powers between the professionals and the artists makes it doubtful that the artist would receive fair compensation, but it is easy to see where a colorable argument for inalienability might originate. Arguments against waiver would be much the same.

234. See Turner, supra note 7, at 344-47, n.97 (discussing the common rationales behind 
transferred, assigned, or waived except for purposes of collective management or other agency. ${ }^{235}$ Similarly, the EVAA forbids waiver, but lacks a positive statement that the right is inalienable. ${ }^{236}$ This is a glaring problem which could prevent the act from functioning as intended. ${ }^{237}$

Some view resale royalties as a taking. ${ }^{238}$ This can cause negative sentiment, particularly against private entities collecting royalties. Scholars suggest that

one's comfort level that the funds will be distributed fairly and in a way that promotes the best interests of the museums and the public is only as high as one's confidence in the collection societies themselves. . . . The delegation of this sort of official authority to private, profitmaking organizations may be seen by some as troubling. ${ }^{239}$

It seems that these arguments might be addressed by enhancing the transparency of the actions of collection societies. ${ }^{240}$ As part of this, the societies could be subrogated to the Copyright Register's authority for reporting and audit purposes, as other countries subrogate their societies to government agencies, such as a Ministry of Culture. ${ }^{241}$ The greater a society's tie to the government, the more likely it is that they will perform as agents of the government. ${ }^{242}$

and criticisms of the resale royalty right for visual artists and the economic aspects of these).

235. U.S. COPYRIGHT OFFICE, supra note 110, at $\mathrm{xx}$ (noting that the U.S. Copyright Office recommends transferability for this purpose); see also infra Appendix A (only one of forty-one countries is not described as "inalienable" or "absolutely inalienable" apart from transfer for agency purposes: Estonia).

236. Equity for Visual Artists Act of 2011, H.R. 3688, 112th Cong. (2011).

237. For an international comparison see supra Part III.B.7.

238. Emily Eschenbach Barker, The California Resale Royalty Act: Droit de [Not So] Suite, 38 Hastings Const. L.Q. 387, 387-88, 390-93 (2011) (discussing the collection system in California.

239. Fishman \& Laird, supra note 188. Cf. Kelo v. City of New London, 545 U.S. 469 (2005) (concerning complaints over a city exercising its eminent domain powers to confiscate homes in order to give the property to Pfizer, a private company).

240. See Virginia J. Morrison, Ancient Culture and Contemporary Art: Protecting Australia's Indigenous Cultural Expression in a Modern IP Framework, 5 LANDSLIDE 33 (2013), archived at http://perma.cc/MPR4-X7VY.

241. For example, Cameroon does this. See infra Appendix A.

242. Barker, supra note 238, at 393-96 (suggesting that if the royalties were funneled through the government it might legitimize it as a tax). The same suggestion could work outside the context of taxes because the key concerns that money is spent "for the benefit of all." Because the US copyright system has a utilitarian basis, an argument may be made that benefitting the individual benefits us all — society has an interest in progressing the arts. 


\section{Problems of Information (Tracking, Remitting, and Enforcement)}

Secrecy norms, which permeate the art market, make tracking sales of specific works difficult. ${ }^{243}$ Artists employ a mechanism to overcome lesser bargaining power that exacerbates the problem-blacklisting people who "flip" their work. ${ }^{244}$ The secrecy norm is also problematic because it interferes with the establishment of provenance, ${ }^{245}$ which is important not only to museums, ${ }^{246}$ but to any owner of a work of visual art. Such "information asymmetry" may distort the working of the market and open the door to many "inefficient outcomes"-valuation errors, fraud, deceit, money laundering, theft, adverse possession, etc. ${ }^{247}$ Some of these outcomes could leave a good faith purchaser vulnerable to replevin or repatriation. ${ }^{248}$

Similarly, secrecy norms in the art market also interfere with collection and remittance of royalties through the inability to locate relevant parties. $^{249}$ Secrecy norms in the art market make enforcement of the law difficult because they allow parties to actively work against the law ${ }^{250}$ sellers can circumvent the royalty by limiting sales to individuals who transact privately without the aid of dealers or anonymous forums.

243. See generally Turner, supra note 7, at 350-56 (giving a detailed discussion of secrecy norms in the art market). Significantly, the author notes that roughly sixty percent of the art market is comprised of private sales. Turner, supra note 7, at 350-51.

244. Edward Winkleman, The Case for Droit de Suite in New York: What's Up With All the Secrecy and Touchiness About a Simple Transaction?, ART NEWSPAPER (Apr. 28, 2010), http://www.theartnewspaper.com/articles/The-case-for-droit-de-suite-in-New-York/20673, archived at http://perma.cc/US8T-V3CR; see also THORNTON, supra note 195, at 8 (noting that in modern times primary dealers try to avoid selling works to people who will flip them because it affords the dealer more control over pricing of the artist's works).

245. Provenance Research, MUSEUM FOLKWANG, http://www.museumfolkwang.de/en/collection/painting-sculpture-media-art/provenance-research.html (last visited Oct. 9, 2013, archived at http://perma.cc/L846-79HK).

246. Id.; see also Provenance Research Project, Metropolitan Museum of ART, http://www.metmuseum.org/research/provenance-research-project (last visited Nov. 9, 2013, archived at http://perma.cc/S5V9-J5VV) (discussing importance of provenance work).

247. Turner, supra note 7, at 355-56; Malcom Bell III, Who's Right? Repatriation of Cultural Property: Two Experts Debate Whether Art and Artifacts Should be Repatriated, IIP DigitAL (Nov. 2, 2010), http://iipdigital.usembassy.gov/st/english/publication/ 2010/10/20101022140412aidan0.7519953.html\#ixzz2N1Wu7SfT, archived at http://perma.cc/KTS3-4HRQ (noting that cultural property is often repatriated); Aaron Milrad, The Discovery Rule, ART CELlaR ExChANGE, http://www.artcellarexchange.com/ artlaw4.html (last visited Sept. 20, 2013, archived at http://perma.cc/NX4L-9D6Q) (noting that innocent purchasers can still be affected by replevin through the discovery rule).

248. Ashton Hawkins et al., A Tale of Two Innocents: Creating an Equitable Balance Between the Rights of Former Owners and Good Faith Purchasers of Stolen Art, 64 FORDHAM L. REV. 49, 49 (1995), archived at http://perma.cc/83KX-UYY7; Milrad, supra note 247.

249. Turner, supra note 7, at 357-59.

250. See Turner, supra note 7, at 357-59. 
Curiously, all forty-one countries limit the scope of resale royalties to works sold publicly or through dealers. ${ }^{251}$ Hence, the legislation in all fortyone countries avoids addressing the potential problem of a sales shifting to the private sector. Some scholars suggest that the best way to address this issue is through the maintenance of a register. ${ }^{252}$ Conversely, others maintain that this type of problem simply does not exist, or at least has no real impact on the collection of royalties. ${ }^{253}$ Even where this is true, it may be beneficial to revisit the idea. ${ }^{254}$

\section{B. The Key Elements of the EVAA Compared with Established International Provisions}

The following sections comment on the EVAA and examine resale royalty legislation of forty-one countries: Algeria, Australia, Austria, Belgium, Benin, Bissau, Bolivia, Brazil, Burkina Faso, Bulgaria, Cameroon, Colombia, DR Congo, Czech Republic, Denmark, Ecuador, Estonia, Finland, Germany, Greece, India, Hungary, Iceland, Ireland, Latvia, Liechtenstein, Lithuania, Malta, Norway, Peru, Poland, Portugal, Romania, Senegal, Slovakia, Slovenia, Spain, Sweden, Chad, Togo, Tunisia, and the United Kingdom. Colombia, France, Italy, Luxembourg, the Netherlands, Central African Republic, Côte d'Ivoire, Equatorial Guinea, Guinea, Gabon, Mali, Mauritania, Niger, and the Russian Federation were also investigated. Colombia and Niger have not implemented a resale royalty right, despite commands to do so from their respective trading blocs, ${ }^{255}$ and as of this writing there were no reliable English translations via the internet for the remaining countries. ${ }^{256}$

251. See infra Appendix B (comparing the scope of various legislations reveals a trend to limit coverage to public sales or sales involving dealers); see also infra Appendix A (see, for example, Hungary whose provisions are extensive and still do not mention this).

252. Turner, supra note 7, at 366-70.

253. See supra Part III.A.I (discussing the traits of the arts market and practical experience of countries employing a resale royalty). Hence, it is reasonable that legislators have not seriously considered this aspect. However, exponential changes in modern technology may make this worth reconsidering.

254. See infra Part IV.C (suggesting that sales between private individuals may be coverable if a desire to self-report is generated).

255. For example, the Andean Community and the African Organization on Intellectual Property have commanded Colombia and Niger, respectively, to implement a resale royalty right. See infra Appendix A. The chart on royalty legislation for the Andean Community (CAN), African Organization on Intellectual Property (OAPI), Columbia, and Niger depicts similar information. See infra Appendix B.

256. There is a chart for international legislation indicating countries assessed for this Note and which countries had no reliable English language translation. See infra Appendix B. 


\section{Scope}

The EVAA restricts application of resale royalties to auction re-sales, meaning sales at public auction houses in which prior year sales totaled more than $\$ 25$ million. $^{257}$ International sources are quite different. Internationally, the scope devolves into four categories of increasing breadth: public auction re-sales only; ${ }^{258}$ public auction re-sales plus re-sales by a dealer or art market professional; ${ }^{259}$ any resale by any professional who regularly works in the art market; ${ }^{260}$ and any resale. ${ }^{261}$ The majority of the countries fall into the middle two categories. ${ }^{262}$ Thus, the scope of resale royalties under the EVAA is the minority position.

\section{Covered Works}

Internationally, the covered works category has two important aspects: specific works covered and the requirement of originality. These are combined in ways that produce several different categories of covered works. The European Union along with many other countries employ a general phrase such as "graphic or plastic art works,"263 "graphic or threedimensional works of art,"264 "works of fine art," followed by a non-inclusive list of specific examples to describe the works covered. ${ }^{267}$ The EVAA is somewhat different in that it employs a general

257. Equity for Visual Artists Act of 2011, H.R. 3688, 112th Cong. §§ 2(1), 3(2) (2011).

258. Belgium and Latvia define the scope of resale royalties narrowly. Latvia is less certain since it says "public resale" but I feel it best fits here. See infra Appendix A. The chart on royalty legislation for Belgium and Latvia depicts similar information. See infra Appendix B.

259. Algeria, Benin, Bolivia, Burkina Faso, Cameroon, DR Congo, Ecuador, Germany, Greece, Peru, Senegal, Chad, Togo, and Tunisia all utilize this definition for the scope of resale royalties. See infra Appendix A. Also look for these countries' information on royalty legislation chart. See infra Appendix B.

260. See infra Appendix A, Australia, Austria, Bulgaria, Czech Republic, Denmark, Estonia, Finland, Iceland, Liechtenstein, Lithuania, Malta, Norway, Poland, Portugal, Romania, Slovakia, Slovenia, Spain, Sweden, and United Kingdom. All utilize this definition for the scope of resale royalties. Also look for these countries' information on royalty legislation chart. See infra Appendix B.

261. Brazil, Guinea-Bissau, and India have the broadest scope of resale royalties. See infra Appendix A. Also look for these countries' information on royalty legislation chart. See infra Appendix B.

262. See generally infra Appendix A; infra Appendix B.

263. See infra Appendix A, European Union and the United Kingdom, for example.

264. See id. Benin, for example.

265. See id., Greece, for example.

266. See id., Ireland, for example.

267. Sixteen countries and the European Union including the, for example, Bulgaria, and Australia. See id. See also infra Appendix B, row for "covered works." 
phrase, "work of visual art," ${ }^{268}$ but seems to limit that term to a concrete list: "a painting, drawing, print, sculpture or photograph." ${ }^{269}$ This definition seems very narrow compared to others and might rule out future forms of visual art not now known.

In terms of originality, there is a prevailing trend of stating an explicit originality requirement. ${ }^{270}$ Only seven out of forty-one countries have no such requirement. ${ }^{271}$ Of the three wider regions examined, only the European Union has an originality requirement. ${ }^{272}$ Further, among those countries and regions with an originality requirement, the European Union and twenty countries allow copies in limited quantity, typically numbered, signed, and authorized in some manner, to constitute "original" works. ${ }^{273}$ With some countries, the originality requirement is very broad, ${ }^{274}$ with others it is very narrow. ${ }^{275}$ The EVAA has an explicit originality requirement which allows for certain copies. ${ }^{276}$ Hence, the EVAA accords with the largest international position.

\section{Price Floors and Ceilings}

Of the three regions examined, only the European Union has a minimum price. ${ }^{277}$ Internationally, seventeen out of forty-one countries examined have no minimum price. ${ }^{278}$ Of the remaining countries, minimum price floors range from approximately $\$ 83$ to $\$ 4,900$ equivalent, ${ }^{279}$ with

268. Equity for Visual Artists Act of 2011, H.R. 3688, 112th Cong. § 2(5) (2011) (definition of "work of visual art").

269. See infra Appendix A.

270. See id. (noting thirty countries explicitly require originality; Denmark, Finland, Spain, and the United Kingdom impliedly require it). See also infra Appendix B, row for "covered works."

271. See infra Appendix A, Bolivia, DR Congo, Malta, Peru, Chad, Togo, Tunisia.

272. See infra Appendix A.

273. See infra Appendix A., Austria, Belgium, Bulgaria, Czech Republic, Denmark, Estonia, Finland, Hungary, Latvia, Lithuania, Poland, Portugal, Romania, Slovakia, Slovenia, Spain, Sweden, United Kingdom, Liechtenstein, Norway.

274. Tunisia is an example. See infra Appendix A.

275. For example, Brazil defines "original" as the "initial creation." See infra Appendix A (Brazil); Appendix B (column for Brazil, row for covered works).

276. Equity for Visual Artists Act of 2011, H.R. 3688, 112th Cong. § 2(5) (2011) (definition of "work of visual art").

277. See infra Appendix A, European Union; infra Appendix B (chart column for European Union).

278. Algeria, Benin, Bolivia, Brazil, Burkina Faso, Cameroon, DR Congo, Ecuador, Guinea-Bissau, Greece, Iceland, Latvia, Peru, Senegal, Slovenia, Togo, and Tunisia have no minimum price. See infra Appendix A; see also corresponding chart columns infra Appendix B.

279. Estimates were calculated Mar. 10, 2013, using Google Bar Currency Calculator; the minimum price range excludes Sweden whose minimum price is based on an amount set by the Swedish National Insurance Act 1962:381, which is not available on the internet in 
most countries having a minimum price of approximately $\$ 4,000$ or less. ${ }^{280}$ By comparison, the EVAA sets a minimum price of $\$ 10,000 .{ }^{281}$ At first blush, this seems extremely high. However, some countries provide that within three years of an artist's initial sale to a dealer, the applicable minimum is EUR $10,000 .{ }^{282}$ Since the EVAA is narrowly tailored to apply only to public auction sales, ${ }^{283}$ it likely hits more dealers than not, ${ }^{284}$ thereby revealing some similarity between the two. However, the EVAA would still be relatively high because as a minimum price it applies universally. Also, those countries with the special provision represent the minority view.

At the other end of the price spectrum, the European Union imposes a cap on royalties of EUR 12,500. ${ }^{285}$ Accordingly, twenty of the twenty-two EU countries examined, plus Iceland and Norway, employ such a cap. ${ }^{286}$ Liechtenstein also has a cap that is slightly higher. ${ }^{287}$ None of the countries existing outside of the European Economic Trading Area which were examined employ a cap. ${ }^{288}$ The EVAA similarly has no cap. ${ }^{289}$ Some suggest that having a cap might limit the impact of the royalty to the arts market. ${ }^{290}$ Presumably this view stems from the certainty that results in knowing the maximum out-of-pocket expense one might have to pay. However, it is not clear whether having a cap makes a significant difference, given that countries without caps have achieved success. ${ }^{291}$

the English language.

280. See infra Appendix B. Nine countries have a minimum price of approximately $\$ 1,500$ or less as calculated Mar. 10, 2013, using Google Bar Currency Calculator; twentytwo countries have a minimum price of approximately $\$ 3,000$ or less; and only Liechtenstein has a minimum price with an approximate value above \$4,000. Id.; see also infra Appendix A. It should be noted that Belgium is an EU Member, but they have not yet made available to WIPO any implementing legislation. See also Belgium, World Intellectual Property ORG., http://www.wipo.int/wipolex/en/profile.jsp?code=BE (last updated Apr. 19, 2013, archived at $\mathrm{http}: / /$ perma.cc/AZ4V-M2W8).

281. H.R. $3688 \S 3(3)$.

282. Austria, Bulgaria, Liechtenstein, Malta, Spain, and United Kingdom are all examples. See infra Appendix A. See also infra Appendix B (corresponding countries' chart columns indicating that this special provision is optional at the EU regional level and applied for five countries-Austria, Bulgaria, Malta, Spain, United Kingdom; Liechtenstein has a similar provision that is set slightly higher at 15,600 francs).

283. H.R. $3688 \S 3(2)$.

284. THORNTON, supra note 195 , at 8 .

285. See infra Appendix A; infra Appendix B.

286. See infra Appendix A, Austria, Bulgaria, Czech Republic, Denmark, Estonia, Finland, Germany, Hungary, Ireland, Latvia, Lithuania, Malta, Poland, Portugal, Romania, Slovakia, Slovenia, Spain, Sweden, United Kingdom, Iceland, Norway; infra Appendix B, columns for same.

287. See infra Appendix A, Liechtenstein; infra Appendix B, chart column for Liechtenstein.

288. Id.

289. See Equity for Visual Artists Act of 2011, H.R. 3688, 112th Cong. (2011).

290. Design AND ARTists Copyright Society, supra note 230, at 10.

291. See, e.g., ReSAlE RoyAlty, supra note 91 and accompanying text. 
Hence, the lack of a cap likely has little impact on the functioning of the EVAA.

\section{Collection and Remittance}

Of the three regions examined, only the European Union commands its Members to use collective management. ${ }^{292}$ Eight of the forty-one countries examined have legislation that is absent or not clear as to whether collective management was required. ${ }^{293}$ Eighteen countries have express or implied provisions for mandatory collective management; of these, only twelve are EU Members. ${ }^{294}$ Two countries, Australia and Peru, have default provisions for collective management which authors may choose not to use. $^{295}$ The remaining twenty-two countries make use of collective management optional. ${ }^{296}$ The EVAA has a mandatory collective management provision. ${ }^{297}$ This provision is likely to be crucial to the functioning of the statute. Although use of collective management bodies appears to be in the minority view, the best data available on the functioning of royalty statutes comes from these countries. ${ }^{298}$

\section{Duration}

Under the EVAA, the royalty right applies for the life of the author plus seventy years. ${ }^{299}$ This provision accords with all three regions examined and a vast majority of the countries as well. ${ }^{300}$

292. See infra Appendix A; infra Appendix B.

293. Algeria, Austria, Burkina Faso, DR Congo, Germany, Guinea-Bissau, Ireland and Portugal. See infra Appendix A; infra Appendix B, columns for same.

294. Czech Republic, Denmark, Estonia, Finland, Hungary, Latvia, Romania, Slovakia, Slovenia, Spain, Sweden, United Kingdom, Benin, Bolivia, Iceland, Norway, Togo, and Tunisia all had mandatory collective management provisions. See infra Appendix A; infra Appendix B. But see infra Appendix A, India. India's provisions are voluntary pending the establishment of a national collective management organization, at which time it becomes compulsory.

295. See infra Appendix A, Australia, Peru; infra Appendix B, columns for same.

296. Id. But see infra Appendix A, India. India's provisions are voluntary pending the establishment of a national collective management organization, at which time it becomes compulsory.

297. Equity for Visual Artists Act of 2011, H.R. 3688, 112th Cong. § 3(2) (2011) ("royalty shall be paid to a visual artists' collecting society.").

298. See supra Parts II.A.1, 4 (discussing various successes).

299. H.R. $3688 \S 3$ (amending the exclusive rights of the Copyright Act which are subject to the duration requirements therein); 17 U.S.C. $\S \S 302-305$ (2012) (duration).

300. See infra Appendix A; infra Appendix B, chart row indicating "duration" for the regions and countries. 


\section{Rate}

Of the three regions examined, only the European Union provides for a specific rate. ${ }^{301}$ Twenty of the twenty-two EU countries examined employ a multi-tiered rate, as do Iceland, Norway, and Liechtenstein; the remaining two employ a flat rate of the sales price. ${ }^{302}$ Of the remaining countries, nine employ a flat rate of the sales price ${ }^{303}$ one employs a percent of increase in price up to a certain point and then a flat rate on the sales price after; ${ }^{304}$ one employs a percent of gain in value, ${ }^{305}$ three employ a percent-of-theproceeds approach; ${ }^{306}$ one lets the collectives decide the flat rate percentage so long as it does not exceed 10 percent; ${ }^{307}$ and one has never set a rate. ${ }^{308}$ No one outside the EEA has adopted a multi-tiered approach. ${ }^{309}$

The EVAA is most similar to countries employing a flat-rate percentage. The two countries with the lowest rates have rates of 3 or 4 percent. ${ }^{310}$ The two countries with the highest rates are both set at 10 percent. ${ }^{311}$ The remaining flat rate countries, excluding India whose scheme is atypical, employ a flat rate of 5 percent. ${ }^{312}$ The EVAA imposes a flat rate of 7 percent of the sales price, but goes further and reserves half, after costs, for a cultural fund so that less than half of what was initially collected actually disburses to the artist. ${ }^{313}$ In other words, an artist could receive between $2.5 \%$ and $3.5 \%$ of the royalty, depending on the amount of costs deducted. Compared to other countries, this range seems woefully low.

301. See infra Appendix A.

302. Belgium and Greece employed a flat rate of the sales price. See infra Appendix A; see also infra Appendix B, chart columns for Belgium and Greece.

303. See infra Appendix A, Algeria, Australia, Burkina Faso, Bolivia, Cameroon, Ecuador, Peru, Senegal, Chad; infra Appendix B, chart columns for same.

304. See infra Appendix A, Guinea-Bissau; infra Appendix B, chart column forsame.

305. See infra Appendix A, Brazil; infra Appendix B, chart columns for same.

306. See infra Appendix A, Benin, Togo, Tunisia; infra Appendix B, chart columns for same.

307. See infra Appendix A, India; infra Appendix B, chart column for same.

308. See infra Appendix A, DR Congo; infra Appendix B, chart column for same.

309. See generally infra Appendix A; infra Appendix B.

310. See infra Appendix A, Belgium; infra Appendix B, chart columns for Belgium, Peru.

311. See infra Appendix A, Burkina Faso, Chad; infra Appendix B, chart columns for same.

312. See infra Appendix A, Australia, Bolivia, Cameroon, Ecuador, Greece, Senegal; infra Appendix B, chart columns for same.

313. Equity for Visual Artists Act of 2011, H.R. 3688, 112th Cong. §§ 3(2), 6(2) (2011) (providing for collective management fees of up to eighteen percent and copyright office fees of up to five percent). 


\section{Alienability}

The alienability debate seems to have been resolved, since all but one country has concluded the right should be inalienable. ${ }^{314}$ Additionally, the decision is unanimous at the regional level. ${ }^{315}$ However, textually speaking there is some strangeness about the way countries handle this right. Despite the label of "inalienable," many countries allow for or require transfer of the right to a collective management entity, as well as continuing rights after death. ${ }^{316}$ This suggests that something less than "absolute inalienability" and more like "checked inalienability" is being applied in support of agency principles. The EVAA differs in this regard because it does not expressly state that the right is inalienable. ${ }^{317}$ With so many countries choosing to make the resale royalty right inalienable, it is curious that the United States did not do so. The lack of explicit terms regarding transfer could render the legislation ineffective. The concept of inalienability intertwines with the public benefit purpose in the resale royalty context. If authors can freely assign their rights to others then it becomes less clear whether the purpose of the statute is being properly served, especially where there is differential bargaining power between the contracting parties.

\section{Waiver}

Internationally, waiver is much the same as inalienability. Many countries do not mention waiver at all, ${ }^{318}$ but for those that do, all but one has said no waiver. ${ }^{319}$ All three regions unanimously state that there should be no waiver. ${ }^{320}$ The EVAA is not different in this regard. ${ }^{321}$

\section{Devise or Descent}

Devise or descent of the resale royalty right is generally handled in

314. Estonia has not concluded the right to be inalienable. See infra Appendix A; infra Appendix B, chart columns for Estonia.

315. CAN, European Union, and OAPI show unanimous decisions. See infra Appendix A; infra Appendix B, chart columns for CAN, European Union, OAPI.

316. Germany and Lithuania are examples. See infra Appendix A; infra Appendix B, chart columns for same.

317. H.R. $3688 \S 3(2)$.

318. See infra Appendix A, Greece, Hungary, Ireland; see also infra Appendix B, columns for Greece, Hungary, Ireland.

319. See infra Appendix A. Denmark has a limited form of waiver. See infra Appendix B.

320. See infra Appendix A, CAN, European Union, OAPI; infra Appendix B, columns for CAN, European Union, OAPI.

321. H.R. 3688 § 3(2). 
one of two ways: the right may pass to heirs only, or the right may pass to heirs or other legal successors, such as legatees. ${ }^{322}$ However, there are some variations on this theme. Two countries have allow a "successor in title" to take, ${ }^{323}$ and eleven countries provide that if there are no heirs the right shall pass to the government or to an approved collective management entity. ${ }^{324}$ Curiously, the EVAA contains no provisions regarding devise of the right. ${ }^{325}$ This could engender litigation or otherwise create legal uncertainty upon the death of a qualified author.

\section{Exclusions}

The European Union and the OAPI both exclude architectural work and applied art. ${ }^{326}$ The European Union also excludes manuscripts. ${ }^{327}$ Internationally, countries tend to varyingly exclude architectural works, applied art, manuscripts, audiovisual works, and photographs. ${ }^{328}$ The EVAA does not contain any specific exclusions, ${ }^{329}$ but as it was introduced none were needed because the covered works were defined narrowly and inclusively. ${ }^{330}$ If the covered works were redefined in the legislative process then the exclusions should be revisited as well.

\section{Formalities}

At this time only Austria has any formality requirements. ${ }^{331}$ Austria acceded to the European Union in $1995^{332}$ and as part of that accession should be working towards eliminating such formalities. In fact, they may

322. For examples of the former, see infra Appendix B, columns for Algeria, Greece, Poland. For examples of the latter, see infra Appendix B, columns for DR Congo, Ecuador, Latvia.

323. See infra Appendix A, Germany, Chad; see also infra Appendix B columns for same.

324. See infra Appendix A, Bulgaria, Czech Republic, Denmark, Finland, Romania, United Kingdom, Bolivia, Iceland, Norway, Senegal, Tunisia; infra Appendix B, columns for same .

325. See H.R. 3688.

326. See infra Appendix A, European Union, OAPI; infra Appendix B, columns for European Union, OAPI.

327. See infra Appendix A, European Union; infra Appendix B, column for European Union.

328. See infra Appendix B (offering a variety of exclusions across the "Excludes" row of the international legislation chart).

329. See H.R. 3688 §2(5).

330. See id.

331. See infra Appendix A, Austria; infra Appendix B, column for Austria.

332. Austria, EuropA.EU, http://europa.eu/about-eu/countries/membercountries/austria/index_en.htm (last visited Jan. 23, 2014, archived at http://perma.cc/TW8E-5E3V). 
have already done so, but an English language translation of a more modern law might simply be lacking at the time of this writing. Likewise, there are no formalities necessary to receive benefits under the EVAA; the usual creation requirement under the Copyright $\mathrm{Act}^{333}$ is sufficient.

\section{Information Rights}

More than half of the countries examined provide the author or relevant collective management entity a right to certain information in order to facilitate royalty collection. ${ }^{334}$ Generally, a time limit of three years is placed on the ability to exercise this right that runs from the resale date or from notice to the author or collection entity. ${ }^{335}$ However, there is some variation that includes no mention of a time frame, a very short time frame, or an annual ability. ${ }^{336}$ Importantly, the EVAA does not provide such a right to information, ${ }^{337}$ which is unfortunate because an information right provides a partial solution to the information problem that plagues this type of law. ${ }^{338}$ Hence, the EVAA should be revised to include such a right.

\section{Foreigners}

The European Union prescribes reciprocal rights for foreigners at the regional level, CAN delegates the decision to Member countries, and OAPI provides that collective management entities may choose to deal with foreigners according to the terms of relevant conventions and agreements. $^{339}$ Of the forty-one countries examined, twenty-nine have a reciprocal rights requirement for foreigners; ${ }^{340}$ four are silent on the

333. See 17 U.S.C. $§ 102$ (2012).

334. See generally Appendix A, Austria, Belgium, Bulgaria, Czech. Republic, Denmark, Estonia, Finland, Germany, Greece, Hungary, Ireland, Latvia, Lithuania, Malta, Poland, Portugal, Romania, Slovenia, Spain, Sweden, United Kingdom, Australia, Cameroon, Iceland, Liechtenstein, Norway, Senegal; infra Appendix B columns for same.

335. See infra Appendix A, nineteen countries - Austria, Bulgaria, Czech. Republic, Estonia, Finland, Germany, Hungary, Ireland, Latvia, Poland, Portugal, Romania, Slovenia, Spain, Sweden, United Kingdom, Iceland, Liechtenstein, Norway; infra Appendix B, columns for same.

336. See e.g., Appendix A, Belgium (no time frame mentioned), Australia (60 day period), Greece (once per year); infra Appendix B, columns for same.

337. See Equity for Visual Artists Act of 2011, H.R. 3688, 112th Cong. (2011).

338. See generally Turner, supra note 7.

339. See infra Appendix A, CAN, European Union, OAPI; infra Appendix B, columns for CAN, European Union, OAPI.

340. See generally infra Appendix A, Belgium, Bulgaria, Algeria, Czech. Republic, Denmark, Estonia, Finland, Germany, Hungary, Latvia, Lithuania, Poland, Portugal, Romania, Slovakia, Slovenia, Spain, Sweden, Tunisia, Australia, Bolivia, Brazil, Cameroon, DR Congo, Iceland, Liechtenstein, Norway, Senegal; infra Appendix B columns for same countries, row for "foreigners". 
issue $;{ }^{341}$ two provide the royalty can apply regardless of nationality or domicile; ${ }^{342}$ and six limit the right to qualified individuals or territories or pursuant to relevant treaties in force where the country was a signatory. ${ }^{343}$ The EVAA has no similar provision. ${ }^{344}$ This could become problematic if any non-US residents attempt to collect in the United States. Because there is no provision for this sort of thing, their rights are uncertain.

\section{Enforcement}

Eighteen countries have specific provisions reinforcing the right to a royalty or the right to information in order to collect the royalty, or both, apart from the usual remedies for copyright violations. ${ }^{345}$ This type of provision tends to provide for fines or damages whenever the party charged with liability for the royalty - such as an art market professional - fails to remit the funds or the necessary information. ${ }^{346}$ The EVAA provides that failure of the "entity collecting the money or other consideration resulting from the sale of the work to pay the royalty provided under this section shall constitute an infringement . . . subject to statutory damages under section 504." "347 Section 504 damages generally means "a sum of not less than $\$ 750$ or more than $\$ 30,000$ as the court considers just, ${ }^{, 348}$ unless mitigated by innocent conduct to "a sum not less than $\$ 200$ "349 or aggravated by willful conduct to "a sum not more than $\$ 150,000 . "$ " this provision accords with the provisions of other countries. However, if in the legislation process an information right is added then separate enforcement provisions for this right should be considered.

\section{COMMENT/CONCLUSION}

\section{A. How Effective Is the Legislation Likely to Be?}

An examination of the EVAA in light of prior US efforts, and

341. See infra Appendix A, Austria, Guinea-Bissau, Greece, India; infra Appendix B columns for same.

342. See infra Appendix A, Ecuador, Peru; infra Appendix B columns for same.

343. See infra Appendix A, Ireland, United Kingdom, Australia, Benin, Burkina Faso, Chad; infra Appendix B columns for same.

344. See Equity for Visual Artists Act of 2011, H.R. 3688, 112th Cong. (2011).

345. See infra Appendix A, Belgium, Czech Republic, Denmark, Estonia, Finland, Latvia, Malta, Poland, Romania, Slovenia, Australia, Benin, Burkina Faso, Cameroon, , Iceland, Norway, Chad, Togo; infra Appendix B columns for same.

346. See infra Appendix B, row for "enforcement."

347. H.R. $3688 \S 3(2)$.

348. 17 U.S.C. $\S 504(c)(1)(2012)$.

349. 17 U.S.C. $\$ 504(c)(2)$.

350. Id. 
compared with the legislative efforts and experiences of other countries, reveals that there are several aspects of resale royalty legislation that could prove problematic, and which the EVAA fails to address. Perhaps most important are the problems with alienability and information, which are not reflected in the text of the bill. Beyond these concerns, there are problems with the narrow scope of the right and the inclusion of an unusually high resale price threshold. Together, this tetrad of problems could create a substantial barrier to meaningful implementation of the right. Hence, there is reason to believe that the EVAA, as introduced, would be ineffective.

\section{B. What Specific Changes Are Necessary to Make the Legislation Effective?}

There are several changes that might make the EVAA more effective and bring it more in line with international legislation. First, drafters should decide on a purpose and incorporate it clearly so the statute sends a cohesive message as to its aims. Second, the scope should be enlarged to include all art market professionals, whether galleries or private dealers. Third, the works covered should be rephrased as a non-inclusive list with a small sub-set of exclusions to provide some flexibility for future creations. Fourth, the price threshold should be lowered to a more reasonable amount, such as $\$ 500$ or $\$ 1,000$. At $\$ 10,000$, it is possible that most authors will not benefit from the right. ${ }^{351}$ It may also be worth considering whether a cap on the royalties would work better-with this route, presumably more authors would benefit and purchasers could be assured of a maximum expenditure. Fifth, if legislators want to have an up-front split of the royalty, then the rate needs to be higher. Other countries with cultural funds take from the back - from royalties which cannot be distributed, rights that escheat after death, a right of the government after the duration has expired, or rights held by the government bona vacantia. ${ }^{352}$ Sixth, and most critical, the EVAA should be revised to clearly state that the right has either absolute or checked inalienability - with absolute it is a right personal to the author and that collective management entities may act as the author's agents in this regard; with checked, that the right may not be transferred except to collective management entities. Seventh, and related, is the subject of devise. Because the resale royalty right is a quasi-moral right, the EVAA must have a provision that addresses this so authors may feel certain that their bequests are legal and will be honored. Eighth, the EVAA needs a right of information to ease enforcement. Finally, the EVAA needs to have some sort of provision clarifying whether the right may apply to foreigners.

351. De Pierredon-Fawcett, supra note 7, at 119 (noting that even $\$ 1,000$ is "extraordinarily high").

352. See infra Appendix A, Bulgaria, Hungary, Malta, Peru, Romania; infra Appendix B, columns for Bulgaria, Hungary, Malta, Peru, Romania, for example. 


\section{What Else Might Be Tried?}

One of the major obstacles to resale rights in general is the natural secrecy of the arts market. ${ }^{353}$ Scholars have recognized this problem and have suggested that the best way to address this problem is to provide an information right and to demand that a registry of sales be kept. ${ }^{354}$ While these are excellent ideas, the latter, at least, is not without problems. The concept of a registry was attempted very early on, but was ultimately rejected as unworkable due to its estimated expense. ${ }^{355}$ Later, concerns as to privacy rights were noted in the Copyright Register's 1992 report. ${ }^{356}$ However, these complaints are very old-decades old. This two-pronged approach provides a convenient starting point.

Ultimately, it has been observed that the EVAA would be relatively easy to enforce since it would apply to very few sales; all that would be needed is to "police an elite group of auction houses, including Christie's and Sotheby's." 357 This cannot be good policy. Additionally, Moore's Law, ${ }^{358}$ which describes the rapid growth of technology, has been interpreted to include concurrent decreases in cost. ${ }^{359}$ Accordingly, since the idea of a registry was last seriously considered more than twenty years ago, the cost of technology has likely dropped considerably. It is for this reason that it is time to reconsider the idea of a registry. Further, the registry should not be limited to just elite sellers. With modern technology, there is little reason why a secured database could not be established, with a simple interphase which would allow anyone to enter information while at the same time restricting database users to information entered by them. With a supporting right to information and a confidentiality provision that are both separately enforceable, privacy rights could be maintained. Legislators could then consider expanding the scope of the right even further. Eventually, the technology might even allow for voluntarily reported private transactions to be entered as well. ${ }^{360}$ Because some suggest that collection of private sales may be too burdensome and expensive to administer, ${ }^{361}$ remittance on a voluntary basis could be an option if it were

353. See supra Part III.A.4.

354. Turner, supra note 7, at 366-70.

355. De Pierredon-FAwCETt, supra note 7, at 3.

356. U.S. COPYRIGHT OFFICE, supra note 110, at ix.

357. Turner, supra note 7, at 364 .

358. Michael Kanellos, Moore's Law to Roll on For Another Decade, CNET NEws (Feb. 10, 2003, 2:27 PM), http://news.cnet.com/2100-1001-984051.html, archived at http://perma.cc/8DVV-8FM6.

359. Robert W. Keyes, The Impact of Moore's Law, 11 Solid-STATE Circuit NeWSLETTER 25 (2006) (means decreasing costs).

360. See Edward Winkleman, supra note 244 (noting that a majority of the arts market is private sales between individuals).

361. Alderman, supra note 183, at 278; see also U.S. COPYRIGHT OFFICE, supra note 
somehow appealing. Ease of completing the transaction could serve this aim. Also, if the EVAA could be considered in the larger framework, tax incentives may also help - for instance, a break in the capital gains tax that generally attaches to such transactions. ${ }^{362}$

Another idea worth considering is the issuance of a title. Chain of title on visual works of art is a real concern for museums that deal with issues of provenance. $^{363}$ When the concept of a registry was initially being considered, it was contemplated that in exchange for taking the time to enter information onto the registry, users would be rewarded with a certificate of authenticity. ${ }^{364}$ This idea is worth investigating again. Since certificates of authenticity currently can function as valuable aspects of sales by artists, ${ }^{365}$ it would be better to consider a certificate of title which may be used in addition to certificates of authenticity. The title could be maintained electronically and updated with each sales transaction, with copies obtainable for a small fee. In this way, the registry could give something of value back to owners. As previously indicated, if title is uncertain a bona fide purchaser could wind up facing replevin or repatriation problems. ${ }^{366}$ Certificates of clean title then, could give purchasers value from certainty that might otherwise be lacking. This type of title might even serve to support an artist's certificate of authenticity by helping establish provenance.

In sum, the EVAA as introduced has several potential flaws. The practical experience of other countries has highlighted problems with purpose, doctrinal conflict, and information. Yet, the EVAA proposes a complex revenue sharing scheme not yet contemplated by other countries without ever addressing these issues. This stance potentially ignores the knowledge amassed by others and risks generating new problems. Consequently, the EVAA needs to be revised to lessen the risk that the legislation will be ineffective.

110, at 66, n.21 (noting objection to California act due to expense).

362. See sources cited supra note 198.

363. See supra notes $245-48$ and accompanying text.

364. De Pierredon-FAwCETt, supra note 7, at 3.

365. Fiona Morgan, All About the Artist's Certificate of Authenticity, WHERE FISH SING (Sept. 12, 2009), http://spacesbetweenthegaps.wherefishsing.com/2009/09/all-about-artistscertificate-of.html, archived at http://perma.cc/6PFE-5U6A.

366. See supra Part III.A.4. 


\section{APPENDIX A: SOURCES OF DDS LEGISLATION}

Andean Community (CAN)

Decisión 351. Régimen Común sobre Derecho de Autor y Derechos Conexos [Common Provisions on Copyright and Neighboring Rights], Gaceta Oficial del Acuerdo de Cartagena [Official Gazette of the Cartagena Agreement], X-No. 145, Dec. 21, 1993 (CAN), archived at http://perma.cc/V93J-UY4E (English language translation by the International Bureau of WIPO).

\section{European Union (EU)}

Directive 2001/84/EC of the European Parliament and of the Council of 27 September 2001 on the Resale Right for the Benefit of the Author of an Original Work of Art, $\S \S(3),(15), 2001$ O.J. (L 272) 32, archived at http://perma.cc/9KT-H6LX.

\section{Organisation Africaine de la Propriété Intellectuelle (OAPI)}

Accord portant révision de l'Accord de Bangui du 02 mars 1977 instituant une Organisation Africaine de la Propriété Intellectuelle [Agreement Revising the Bangui Agreement of 02 March 1977 establishing an African Intellectual Property], signed Mar. 2, 1977 (amended Feb. 24, 1999) (OAPI), archived at http://perma.cc/HC33-D5V9 (English language translation by the International Bureau of WIPO).

\section{Algeria}

2003,

[Copyrights and Neighboring Rights Act of July 19, 2003] (Alg.), archived at http://perma.cc/B38S-6CGK (English language translation by the International Bureau of WIPO).

$\underline{\text { Australia }}$

Resale Royalty Right for Visual Artists Act 2009 (Austl.), archived at http://perma.cc/AVR2-Q5DS.

Austria

BUNDESGESETZ UBER DAS URHEBERRECHT AN WERKEN DER LITERATUR UND DER KUNST UND ÜBER VERWANDTE SCHUTZRECHTE (URHEBERRECHTSGESETZ) 1980 [FEDERAL LAW ON COPYRIGHT IN WORKS OF LiTERATURE AND THE ARTS AND RELATED RigHTS 1980 (COPYRIGHT ACT) (AS AMENDED 2010)], BundesGesetzBlatT I 
[BGB1. I.] NR. 58/2010 (Austria), archived at http://perma.cc/B8SR-J2E6 (automatic translation tool version); see also Austria: 5.1 General Legislation: 5.1.7 Copyright Provisions, COMPENDIUM, http://www.culturalpolicies.net/web/austria.php?aid=517 (last visited Jan. 23, 2014, archived at http://perma.cc/J9YU-CW3N); Resale Royalties, Dorotheum,

http://www.dorotheum.com/fileadmin/user_upload/media/Dateien/agbs_ne u/Folgerecht_neu_2012_EN.pdf (last visited Jan. 23, 2014, archived at http://perma.cc/57SV-EVPW).

\section{$\underline{\text { Belgium }}$}

Loi relative au droit d'auteur et aux droits voisins [Law on Copyright and Neighboring Rights] du 30 juin 1994, modifiée par la loi du 3 avril 19959 (Belg.), archived at http://perma.cc/N4F6-VS5P (coordinated version of the law created by WIPO).

\section{$\underline{B e n i n}$}

Loi $\mathrm{n}^{\circ}$ 2005-30 du 5 avril 2006 relative à la protection du droit d'auteur et des droits voisins en République du Benin [Copyright and Related Rights of the Republic of Benin, Apr. 5, 2006] (Benin), archived at http://perma.cc/4E7-CVS2 (English language translation by the International Bureau of WIPO). For additional information, written in French, on what constitutes an "artist" as well as what rights accrue to such an artist see Décret n²011-322 du 2 avril 2011 portant statut de l'artiste en République du Bénin [Decree No. 2011-322 of 2 April 2011 on the Status of the Artist in the Republic of Benin] (Benin), archived at http://perma.cc/HR98-S7TD (French).

\section{Bolivia}

Ley $\mathrm{N}^{\circ} 1322$ del 13 de abril de 1992 sobre el Derecho el Autor [Law. No. 1322 on Copyright] (Bol.), archived at http://perma.cc/X2TX-CJC9 (English language translation by the International Bureau of WIPO); Decreto Supremo No 23907 del 7 de diciembre de 1994; Reglamento de la Ley de Derecho de Autor [Sup. Decr. No. 23907, Regulations to the Law on Copyright] (Bol.), archived at http://perma.cc/6DLK-K2PH (English language translation by the International Bureau of WIPO).

\section{$\underline{\text { Brazil }}$}

Decreto No. 36, de 19 de Fevereiro de 1998, DiÁRIO OfICIAL DA UNIÃO [D.O.U.] de 20.2.1998 (Braz.), archived at http://perma.cc/HU5YGW4S (English language translation by the International Bureau of WIPO). 


\section{$\underline{\text { Bulgaria }}$}

Закон за авторското право и сродните му права (както е изменен през 2011 г.) [Law on Copyright and Neighboring Rights (as amended in 2011)] (Bulg.), archived at http://perma.cc/7TGV-99EW (English language translation by the International Bureau of WIPO).

\section{Burkina Faso}

Loi $\mathrm{n}^{\circ}$ 032-99/AN du 22 décembre 1999 portant protection de la propriété littéraire et artistique [Law No. 032-99/AN of December 22, 1999 on the Protection of Literary and Artistic Property] (Burk. Faso), archived at http://perma.cc/85U9-D764 (English language translation by the International Bureau of WIPO); Décret $n^{\circ}$ 2000573/PRES/PM/MAC/MCPEA/MJPDH portant tarification du droit de suite sur les oeuvres graphiques et plastiques [Decree $\mathrm{N}^{\circ} 2000$ 573/PRES/PM/MAC/MCPEA/MJPDH on Fixing the Rate of the Droit de Suite (Resale Royalty Right) on Graphic and Three-dimensional Works] (Burk. Faso), archived at http://perma.cc/69WH-G6K6 (English language translation by the International Bureau of WIPO).

\section{$\underline{\text { Cameroon }}$}

Loi ${ }^{\circ}$ 2000/011 du 19 décembre 2000 relative au droit d'auteur et aux droits voisins [Law No. 2000/011 of December 19, 2000 on Copyright and Neighboring Rights] (Cameroon), archived at http://perma.cc/3UQT-U26N (English language translation by the International Bureau of WIPO); Décret $\mathrm{n}^{\circ}$ 2001/956/PM du 1er novembre 2001 fixant les modalités d'application de la loi $\mathrm{n}^{\circ}$ 2000/11 du 19 décembre 2000 relative au droit d'auteur et aux droits voisins [Decree No. 2001/956/PM of November 1, 2001 implementing Law No. 2000/11 of December 19, 2000 on Copyright and Neighboring Rights] (Cameroon), archived at http://perma.cc/P9JD-E8RA (English language translation by the International Bureau of WIPO).

\section{$\underline{D R}$ Congo}

Loi ${ }^{\circ} 24 / 82$ du 7 juillet 1982 sur le droit d'auteur et les droits voisins [Law No. 24/82 of July 7, 1982 on Copyright and Neighboring Rights] (DR Congo), archived at http://perma.cc/P9JD-E8RA (English language translation by the International Bureau of WIPO).

\section{Czech Republic}

Zákon č.121/2000 Coll. (konsolidované), o právu autorském a právech souvisejících $\mathrm{s}$ právem autorským ao změně některých zákonů (autorský zákon), ve znění zákona č. 81/2005 Sb., zákona č. 61/2006 Sb. a 
zákona č. 216/2006 Sb. [Law No. 121/2000 (consolidated), on Copyright and Rights Related to Copyright and on Amendment to Certain Acts (the Copyright Act), as amended by Act No. 81/2005 Coll., Act No. 61/2006 Coll. and Act No. 216/2006 Coll.] (Czech.), archived at http://perma.cc/TXC9-SSGK (English language translation by the International Bureau of WIPO).

Denmark

Bekendtgørelse af lov om ophavsret [The Consolidated Act on Copyright] (Den.), archived at http://perma.cc/3FQP-2CJZ (English language translation by the International Bureau of WIPO).

\section{Ecuador}

Codification No. 2006-13 (Supplement to Official Register No. 426, December 28, 2006) (Ecuador), archived at http://perma.cc/TJY4-JW5F (English language translation by the International Bureau of WIPO); Reglamento a la Ley de Propiedad Intelectual [Regulations under the Law on Intellectual Property] (Ecuador), archived at http://perma.cc/7BLWJFUU (English language translation by the International Bureau of WIPO).

\section{$\underline{\text { Estonia }}$}

Autoriõiguse seadus Vastu võetud 11.11.1992 RT 1992, 49, 615 [Copyright Act, 1992] (Est.), archived at http://perma.cc/6B5E-CFB6 (English language translation by the International Bureau of WIPO).

\section{Finland}

Tekijänoikeuslaki [Copyright Act (Act No. 404 of July 8, 1961, as amended up to April 30, 2010)] (Fin.), archived at http://perma.cc/X7PUAB8G (English language translation by the International Bureau of WIPO). For another unofficial translation of the Copyright Act, see http://www.finlex.fi/en/laki/kaannokset/1961/en19610404.pdf (last visited Jan. 23, 2014, archived at http://perma.cc/QDL5-8VZJ).

\section{Germany}

Gesetz über das Urheberrecht und verwandte Schutzrechte (Urheberrechtsgesetz) (geändert am 17. Dezember 2008) [Law on Copyright and Related Rights (Copyright Act) (as amended on 17 Dec. 2008)], BGB1. I at 2586 (Ger.), archived at http://perma.cc/84RQ-HVV2 (translation by Ute Reusch). 
Greece

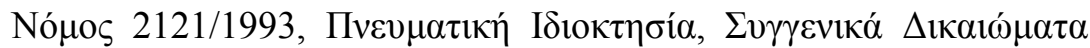

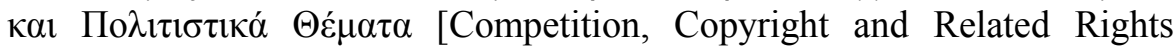
(Neighboring Rights), Enforcement of IP and Related Laws, Industrial Property, IP Regulatory Body, Layout Designs of Integrated Circuits, Patents (Inventions), Trademarks, Undisclosed Information (Trade

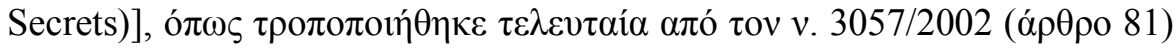

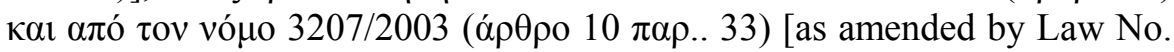
3057/2002 (article 81) and Law 3207/2003 (article 10 par. 33)] (Greece), archived at http://perma.cc/7FUE-KKBK (translation courtesy of UNESCO).

\section{Guinea-Bissau}

Código do Direito de Autor (aprovado pelo Decreto-Lei n ${ }^{\circ} 46.980$ de 27 de Abril de 1966) [Copyright Code (approved by Decr.-Law No. 46.980 of April 27, 1966)] (Guinea-Bissau), archived at http://perma.cc/D53TD3PQ (English language translation by the International Bureau of WIPO).

\section{Hungary}

1999. évi LXXVI. törvény a szerzői jogról [Act No. LXXVI of 1999 on copyright (consolidated text as of Jan. 1, 2014)] (Hung.), archived at Hungarian INTELleCtUAL PROPERTY OFFICE http://perma.cc/86ABPS6U (English language translation courtesy of HIPO). For more unofficial translations see, 1999. évi LXXVI. törvény a szerzői jogról [Act No. LXXVI of 1999 on copyright (consolidated text as of Jan. 1, 2012)] (Hung.), archived at http://perma.cc/4QD2-MNPM (English language translation courtesy of Viktória Kerék, Legal officer of International Copyright Affairs Unit, Hungarian Intellectual Property Organization); 1999. évi LXXVI. törvény a szerzői jogról [Act No. LXXVI of 1999 on copyright (consolidated text as of Jan. 1, 2007)] (Hung.), archived at http://perma.cc/6W9S-DVG2 (English language translation courtesy of UNESCO).

\section{Iceland}

Copyright Act No. 73 of May 29, 1972, as last amended by Act No. 97 of 30 June 2006 (Ice.), archived at http://perma.cc/6B5K-8N7S.

\section{$\underline{\text { India }}$}

The Copyright (Amendment) Act, 1957, No. 14 (as amended by Act No. 49 of 1999), Acts of Parliament, 1999 (India), archived at http://perma.cc/377Q-37V8 (English language translation by the 
International Bureau of WIPO).

Ireland

European Communities (Artist's Resale Right) Regulations 2006 (S.I. No. 312/2006) (Ir.), archived at http://perma.cc/322W-QVLD; European Communities (Artist's Resale Right) Regulations 2006 (S.I. No. 312/2006) (Ir.), archived at http://perma.cc/U62K-2TNR.

\section{$\underline{\text { Latvia }}$}

Autortiesību likums I nodaḷa Vispārīgie noteikumi [Copyright Law (as last amended on Dec. 6, 2007)] (Lat.), archived at http://perma.cc/X9EJ-WG53 (English language translation by the International Bureau of WIPO).

\section{$\underline{\text { Liechtenstein }}$}

Gesetz über das Urheberrecht und verwandte Schutzrechte (Urheberrechtsgesetz, URG) [Law on Copyright and Related Rights (Copyright Law)], Jahrgang 1999 [July 23, 1999], Liechtensteinisches Landesgesetzblatt [Liechtenstein Law Gazette] No. 160 (Liech.), archived at http://perma.cc/SR7D-PC6Q (automatic translation tool).

\section{Lithuania}

1999 m. gegužès 18 d. Autorių teisių ir gretutinių teisių įstatymas Nr. VIII-1185 (su pakeitimais, padarytais $2010 \mathrm{~m}$. sausio 19 d. istatymu Nr. XI656) [Law on Copyright and Related Rights No. VIII-1185 of May 18, 1999 (as amended on Jan. 19, 2010 - by Law No. XI-656)] (Lith.), archived at http://perma.cc/DU22-RS3A (English language translation by the International Bureau of WIPO).

\section{$\underline{\text { Malta }}$}

Att XIII tal-2000, Kap. 415. Att Dwar Id-Drittijiet ta' L-awtur, kif emendat bl-Atti VI ta '1-2001, IX tal-2003 u IX tal-2009. [Act XIII of 2000, Cap. 415. Rights Act of The author, as amended by Acts VI of 2001, IX of 2003 and IX of 2009], archived at http://perma.cc/QV99-8TLY (English language translation by the International Bureau of WIPO). See also L.N. 174 of 2006. Regolamenti ta' 1-2006 dwar id-Dritt ta' Bejgh mill-Ġdid li ghandu Artist [Artists' Resale Right Regulations, 2006] (Malta), archived at http://perma.cc/DNV7-7BQP (English language translation by the International Bureau of WIPO). 
Norway

LOV 1961-05-12 nr 02: Lov om opphavsrett til åndsverk m.v. (åndsverkloven) [Act relating to intellectual property rights (Copyright Act)] (as amended through Dec. 22, 2006) (Nor.), archived at http://perma.cc/9DQR-3Q66.

$\underline{\text { Peru }}$

Ley sobre el Derecho de Autor - Decreto Legislativo $\mathrm{N}^{\circ} 822$ del 23 de april de 1996 [Copyright Law - Legislative Decree No. 822 of April 23, 1996] (Peru), archived at http://perma.cc/VY73-JBJG (English language translation by the International Bureau of WIPO).

$\underline{\text { Poland }}$

Ustawa nr 83. Ustawa z dnia 4 lutego 1994 roku o prawie autorskim i prawach pokrewnych [Law No. 83 of February 4, 1994 on Copyright and Neighboring Rights (as last amended on Oct. 21, 2010)] (Pol.), archived at http://perma.cc/58FS-D6Y5 (English language translation by the International Bureau of WIPO).

\section{$\underline{\text { Portugal }}$}

Decreto-Lei n. ${ }^{\circ}$ 63/85, de 14 de Março, Código do Direito de Autor e dos Direitos Conexos [Code of Copyright and Related Rights], (e alterado pelas Leis n. ${ }^{\circ}$ s 45/85, de 17 de Setembro, e 114/91, de 3 de Setembro, e Decretos-Leis n. ${ }^{\circ}$ s 332/97 e 334/97, ambos de 27 de Novembro, pela Lei n. ${ }^{\circ}$ 50/2004, de 24 de Agosto, pela Lei n. ${ }^{\circ}$ 24/2006 de 30 de Junho e pela Lei n. ${ }^{\circ}$ 16/2008, de 1 de Abril) [(amended by Law n. ${ }^{\circ}$ s $45 / 85$ of Sept. 17, and 114/91 of 3 Sept., and Decree-Law No. Nos 332/97 and 334/97, both of Nov. 27 , by Law No. ${ }^{\circ}$ 50/2004 of 24 August, by Law No. ${ }^{\circ}$ 24/2006 of June 30 and Law No. ${ }^{\circ}$ 16/2008 of 1April)] (Port.), archived at http://perma.cc/WG5G-R45H (automatic translation tool); Lei n. ${ }^{\circ}$ 24/2006 de 30 de Junho (Artist's Resale Right) [Law No. 24/2006 of 30 June (Artist's Resale Right)] (Port.), archived at http://perma.cc/D48K-JDBJ (automatic translation tool).

\section{$\underline{\text { Romania }}$}

Lege nr. 8 din 14 martie 1996 privind dreptul de autor si drepturile conexe [Law No. 8 of March 14, 1996 on Copyright and Neighboring Rights] (Rom.), archived at http://perma.cc/LH8U-EUYQ (English language translation by the International Bureau of WIPO). 
$\underline{\text { Senegal }}$

Loi $\mathrm{n}^{\circ} 2008-09 \mathrm{du} 25$ janvier 2008 sur le droit d'auteur et les droits voisins [Law No. 2008-09 of January 25, 2008 on Copyright and Related Rights] (Sen.), archived at http://perma.cc/DVM2-SD5R (English language translation by the International Bureau of WIPO).

\section{$\underline{\text { Slovakia }}$}

618/2003 Z.z. Zákon zo 4. decembra 2003 o autorskom práve a právach súvisiacich $\mathrm{s}$ autorským právom (autorský zákon) [Act No. 618/2003 on Copyright and Rights Related to Copyright] (Slovk.), archived at http://perma.cc/GKG5-UYKS (English language translation by the International Bureau of WIPO).

\section{$\underline{\text { Slovenia }}$}

Copyright and Related Rights Act of 1995 (as last amended on Dec. 15 2006) Official Gazette RS Nos. 21/95, 9/01, 30/01, 43/01, 17/06, 44/06, $139 / 06$ and 16/07 (in force Jan. 13, 2007) (Slovn.), archived at http://perma.cc/6FDY-PWQ6 (English language translation by the International Bureau of WIPO).

Spain

Texto refundido de la Ley de Propiedad Intelectual, regularizando, aclarando y armonizando las Disposiciones Legales Vigentes sobre la Materia (aprobado por Real Decreto N ${ }^{\circ}$ 1/1996, de 12 de abril de 1996, y modificado por la Ley No 5/1998 de 6 de marzo de 1998, que incorpora la Directiva No 96/9/CE del Parlamento Europeo y del Consejo de 11 de marzo de 1996 relativa a la Protección Jurídica de las Bases de Datos) [Consolidated text of the Law on Intellectual Property, regularizing, clarifying and harmonizing the Applicable Statutory Provisions (approved by Royal Legislative Decree No. 1/1996 of April 12, 1996, and amended by Law No. 5/1998 of March 6, 1998, incorporating Directive 96/9/EC of the European Parliament and of the Council of March 11, 1996 on the Legal Protection of Databases)] (Spain), archived at http://perma.cc/G48QDWBW (English language translation by the International Bureau of WIPO). This version does not reflect the changes made by Law 3/2008. For another unofficial translation see, Ley $3 / 2008$, de 23 de diciembre, relativa al derecho de participación en beneficio del autor de una obra de arte original [Law 3/2008 of 23 December on the resale right for the benefit of the author of an original work of art.] (Spain), archived at GOBIERNO DE ESPANA: MINISTERIO DE LA PRESIDENCIA [Government of Spain: Ministry of the Presidency], http://perma.cc/4S6Q-AXA2 (unofficial 
English language translation readable with Google Translate).

\section{Sweden}

Lag om upphovsrätt till litterära och konstnärliga verk [Act on Copyright in Literary and Artistic Works (1960:729)] (Svensk Författningssamling [SFS] 1960:729) (Swed.), archived at http://perma.cc/3VL2-CUUH (English language translation by the International Bureau of WIPO). For a more recent English language translation see also Lag om upphovsrätt till litterära och konstnärliga verk [Act on Copyright in Literary and Artistic Works (1960:729)] (Svensk Författningssamling [SFS] 1960:729) (Swed.) (English).

Chad

Loi $\mathrm{n}^{\circ}$ 005/PR/2003 du 2 mai 2003 portant Protection du Droit d'Auteur, des Droits Voisins et des Expressions du Folklore [Law No. 005/PR/2003 of May 2nd, 2003 on the Protection of Copyright, Neighboring rights and Expressions of Folklore] (Chad), archived at http://perma.cc/PPB2-5SDQ (English language translation by the International Bureau of WIPO).

$\underline{\operatorname{Tog} O}$

Loi $\mathrm{n}^{\circ}$ 91-12 du 10 juin 1991 portant protection du droit d'auteur, du folklore et des droits voisins [Law No. 91-12 of June 10, 1991 on the Protection of Copyright, Folklore and Related Rights] (Togo), archived at http://perma.cc/8HJM-W8N7 (English language translation by the International Bureau of WIPO).

\section{$\underline{\text { Tunisia }}$}

و الفنية الأدبية بالملكية يتعلق 1994 فيفري 24 في مؤرخ 1994 لسنة 36 عدد قانون [Law No. 94-36 of February 24, 1994, on Literary and Artistic Property] (Tunis.), archived at http://perma.cc/9B64-99WJ (English language translation by the International Bureau of WIPO).

\section{United Kingdom (UK)}

Copyright, Design, and Patents Act, 1988, C.48 (U.K.), (Jan. 21, 2014, 10:39 PM), http://www.legislation.gov.uk/ukpga/1988/48/contents, archived at http://perma.cc/V9SF-XN7E; The Artist's Resale Right (Amendment) Regulations, 2011, S.I. 2011/2873 (U.K.), http://www.legislation.gov.uk/uksi/ 2011/2873/contents/made, archived at http://perma.cc/J392-E84M; The Artist's Resale Right (Amendment) Regulations, 2009, S.I. 2009/2792 (U.K.), $\mathrm{http} / / / w w w . l e g i s l a t i o n . g o v . u k / \mathrm{uksi} / 2009 / 2792 /$ contents/made, archived at 
http://perma.cc/9UVB-BFK3; The Artist's Resale Right Regulations, 2006, S.I. 2006/346 (U.K.), http://www.legislation.gov.uk/uksi/2006/346/contents/ made, archived at http://perma.cc/QP4P-NCPP. For unofficial copies see, Copyright, Design, and Patents Act, 1988, C.48 (U.K.), archived at http://perma.cc/D4QA-6ZGL; The Artist's Resale Right (Amendment) Regulations, 2011, S.I. 2011/2873 (U.K.), archived at http://perma.cc/BE3WP32D; The Artist's Resale Right (Amendment) Regulations, 2009, S.I. 2009/2792 (U.K.), archived at http://perma.cc/52ZR-GL8R; The Artist's Resale Right Regulations, 2006, S.I. 2006/346 (U.K.), archived at http://perma.cc/CB72-UQBD. 


\section{APPENDIX B: DDS LEGISLATION CHARTS}

Viewable and downloadable charts of resale royalty legislation compiled from information freely available from the internet, in the English language, may be found at the companion website to this Note. The relevant web address is http://elisadoll.wordpress.com/, archived at http://perma.cc/BF4U-5M7S. Charts were prepared for easy comparison of international law and for US national law. 